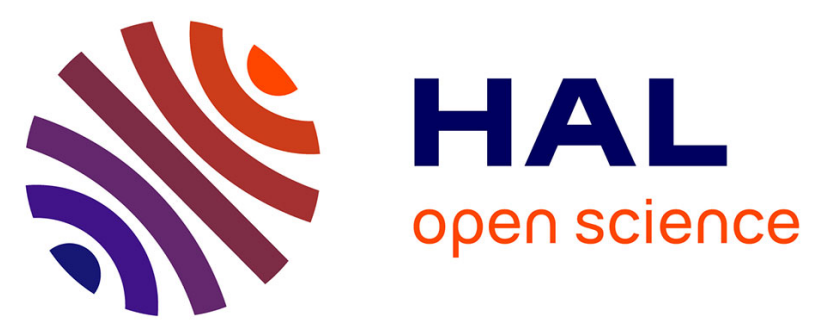

\title{
Transition from collision to subduction in Western Greece: the Katouna-Stamna active fault system and regional kinematics
}

E. Pérouse, Michel Sébrier, R. Braucher, Nicolas Chamot-Rooke, D. Bourles, Pierre Briole, D. Sorel, D. Dimitrov, Stavros Arsenikos

\section{To cite this version:}

E. Pérouse, Michel Sébrier, R. Braucher, Nicolas Chamot-Rooke, D. Bourles, et al.. Transition from collision to subduction in Western Greece: the Katouna-Stamna active fault system and regional kinematics. International Journal of Earth Sciences, 2017, 106 (3), pp.967-989. 10.1007/s00531-0161345-9 . hal-01461336

\section{HAL Id: hal-01461336 \\ https://hal-amu.archives-ouvertes.fr/hal-01461336}

Submitted on 16 Jan 2018

HAL is a multi-disciplinary open access archive for the deposit and dissemination of scientific research documents, whether they are published or not. The documents may come from teaching and research institutions in France or abroad, or from public or private research centers.
L'archive ouverte pluridisciplinaire HAL, est destinée au dépôt et à la diffusion de documents scientifiques de niveau recherche, publiés ou non, émanant des établissements d'enseignement et de recherche français ou étrangers, des laboratoires publics ou privés. 
1 Transition from collision to subduction in Western Greece: The Katouna-Stamna active fault system and regional kinematics

Pérouse $^{1}$ E., M. Sébrier ${ }^{2,3}$, R. Braucher ${ }^{4}$, N. Chamot-Rooke ${ }^{1}$, D. Bourlès ${ }^{4}$, P. Briole ${ }^{1}$, D. Sorel $^{5}$, D. Dimitrov ${ }^{6}$, S. Arsenikos ${ }^{1}$

1: Laboratoire de Géologie, UMR CNRS 8538, PSL Research University, Ecole normale supérieure, 24 rue Lhomond, FR-75005, Paris, France.

Now at: Division of Geological and Planetary Sciences, California Institute of Technology,

11 Pasadena, California, and USA. Curie, FR-75252 Paris CEDEX 05, France.

3: UMR 7193, CNRS, UPMC, case 129, FR-75252 Paris CEDEX 05, France.

4: Aix-Marseille Université, CNRS-IRD-Collège de France, UM 34 CEREGE, Technopôle de 19 l'Arbois, BP80, 13545 Aix-en-Provence, France.

5: Denis Sorel, Saint Jayet, 36190 ORSENNES

6: Department of Geodesy, National Institute of Geophysics, Geodesy and Geography, 
Transition from subduction to collision occurs in Western Greece and is accommodated along the downgoing plate by the Kefalonia right-lateral fault that transfers the Hellenic subduction front to the Apulian collision front. Here we present an active tectonic study of AitoloAkarnania (Western Greece) that highlights how such a transition is accommodated in the overriding plate. An accurate active fault traces mapping is performed on the basis of new multi-scale geomorphic and tectonic observations that provide evidence for active normal and left-lateral faulting along the Katouna-Stamna Fault (KSF), a 65-km-long NNW-striking fault system connecting the Amvrakikos Gulf to the Patras Gulf. We further show that the Cenozoic Hellenides thrusts located west of the KSF are no longer active, either in field observation or GPS data, leading us to propose that the KSF forms the northeastern boundary of a rigid Ionian Islands-Akarnania Block (IAB). Cosmic Ray Exposure measurements of ${ }^{10} \mathrm{Be}$ and ${ }^{36} \mathrm{Cl}$ were performed on a Quaternary alluvial fan offset along the KSF ( $\sim 50 \mathrm{~m}$ leftlateral offset). A maximum abandonment age of $\sim 12-14$ ka for the alluvial fan surface can be determined, giving an estimated KSF minimum geological left-lateral slip-rate of $\sim 4$ mm.yr ${ }^{-1}$, in agreement with high GPS slip-rates $\left(\sim 10 \mathrm{~mm} \cdot \mathrm{yr}^{-1}\right)$. Despite this high slip-rate, the KSF is characterized by subdued morphological evidence of tectonic activity, a gypsum-breccia bedrock and a low level of seismicity, suggesting a dominantly creeping behavior for this fault. Finally, we discuss how the IAB appears to have been progressively individualized during the Pleistocene (younger than $\sim 1.5 \mathrm{Ma}$ ).

48 
Active faults, Collision/Subduction, continental neotectonics, GPS, Western Greece,

\section{Introduction}

The lateral transition from oceanic subduction to continental collision induces deformation in the overriding plate. Western Greece offers the opportunity to investigate the tectonic implications of such a transition. The old Mesozoic Ionian oceanic lithosphere (Catalano et al. 2001; Speranza et al. 2012) subducts below the Peloponnesus while to the north, the nearby thick Apulian carbonate platform, on the same Ionian-Apulian micro-plate (D'Agostino et al. 2008; Perouse et al. 2012), abuts against the NW Greece-Albania foreland fold and thrust belt (Fig. 1). The highly seismic right-lateral Kefalonia transform fault (Figs. 1, 2), connecting the collision and subduction fronts, has been extensively studied (e.g., Louvari et al. 1999; Pearce et al. 2012). Farther east inland, NNW-striking Hellenide units and Neogene fold and thrust system (Clews 1989; Underhill 1989) are overprinted by active E-W striking rifting systems (Gulf of Amvrakikos, Trichonis Lake, Gulf of Corinth and Gulf of Patras, Fig. 3). This distributed extension within the upper plate is possibly related to the Hellenic slab retreat (Jolivet et al. 2010; Perouse et al. 2012; Durand et al. 2014). Among the presently active rifting systems, the Corinth Rift is the one which timing evolution is the best constrained. The earliest stage of extension, distributed over a broad rift system, would have started in Pliocene (oldest syn-rift volcanic deposits are 3.6 to 4 Ma old, Collier and Dart 1991). The deepening of the rift and the deposition of giant fan deltas, which marks the inception of major tectonic activity in the Corinth rift is dated to $\sim 1.7 \mathrm{Ma}$, according to the oldest syn-rift deposits age 
(Rohais et al. 2007a; Rohais et al. 2007b). Then, fault activity progressively migrated northward from 1.5 to $0.7 \mathrm{ka}$, leading to the most recent rifting phase of the Gulf of Corinth (0.7 Ma to present day) where extension is localized on the northward dipping normal faults of the present-day southern Gulf of Corinth (e.g., Jolivet et al. 2010; Ford et al. 2013).

Previous tectonic studies of the Aitolo-Akarnania region (Western Greece) propose an active fault network consisting of a set of Quaternary E-W striking grabens (Amvrakikos Gulf, Trichonis Lake and Patras Gulf, Fig. 3) connected by a NW-striking left-lateral fault zone (Melis and Burton 1988; Clews 1989; Sorel 1989; Underhill 1989). Active left-lateral transtension along this fault system, referred as the Amvrakia or Katouna fault, has been proposed thanks to local tomography (Haslinger et al. 1999), GPS data (Le Pichon et al. 1995; Cocard et al. 1999; Hollenstein et al. 2008; Vassilakis et al. 2011; Chousianitis et al. 2015) and estimated as $\sim 11$ mm.yr ${ }^{-1}$ (GPS slip-rate, Vassilakis et al. 2011). However, no clear geological or morphological evidence for active left-lateral faulting has yet been provided: studies were mainly focused on Cenozoic tectonics of the $\sim \mathrm{N}$ striking Hellenides fold and thrust system in Akarnania (Clews 1989; Underhill 1989), and geological evidence for leftlateral displacement was only observed within Mesozoic limestones (Vassilakis et al. 2006; Vassilakis et al. 2011). The existence of a block in Akarnania bounded to the west by the Kefalonia fault, to the north by the Amvrakikos graben and to the east by a NW-striking leftlateral system joining southward to the Patras-Corinth rift has been suggested (Le Pichon et al. 1995; Cocard et al. 1999; Hollenstein et al. 2008; Konstantinou et al. 2009). In the most detailed model, Vassilakis et al. (2011) proposed that the extension at the western end of the Corinth rift is transferred to the Amvrakikos graben through the Trichonis Lake graben and a left-lateral fault in the Amphilochia valley, defining the northeastern boundary of an “Akarnania fragment". Post-Pliocene out-of-sequence reactivation of the N-striking Neogene 
Hellenides thrusts in Akarnania (Clews 1989) as well as present-day normal faulting

99 (Vassilakis et al. 2006) point to possible active internal deformation within this block.

100 The aims of our study are to accurately define the NNW striking fault system of Aitolo-

101 Akarnania, here informally termed the Katouna-Stamna Fault (KSF), and determine whether

102 internal deformation occurs within the Akarnania block, along the N-striking Akarnania

103 thrusts. Based on the analysis of satellite images, Digital Elevation Model and field studies,

104 we performed a critical reappraisal of published data, conducted an accurate mapping of 105 active fault traces in the region, and collected multi-scale geomorphologic observations that provide evidence for active normal and strike-slip faulting, especially left-lateral displacement along the KSF. We further estimated a minimum geological slip rate for the KSF measuring

$108{ }^{10} \mathrm{Be}$ and ${ }^{36} \mathrm{Cl}$ cosmogenic radionuclides produced in-situ. Our new results on the active 109 tectonics of Akarnania are discussed in the light of existing and new GPS data.

\section{Morphotectonic study of Aitolo-Akarnania}

111 Figure 3 is a map summarizing active and inactive major structures of Western Greece from our reappraisal of the tectonics of the Akarnania region. In our study, we consider faults to be "active" if they control the landscape morphology at first order (offset streams, structural

114 landscape, upward convex shaped profile, etc.) and/or if they offset Quaternary deposit. By 115 opposition, faults are considered to be "inactive" when the landscape morphology results mainly from erosional processes. Our contributions to the figure 3 map concern the Katouna-

117 Stamna Fault (KSF, Fig. 4), its northward termination onto the Loutraki fault and a 118 reappraisal of the N-striking Akarnania thrusts, located west of the KSF (Fig. 3, 4). 
122 One prominent geomorphic feature in Akarnania is the remnant of a large uplifted paleosurface on Triassic breccias, tilted $\sim 4^{\circ}$ southward, $\sim 700-\mathrm{m}$ high, south of the Amvrakikos

124 Gulf nearby the Katouna valley (Figs. 4, 5). This paleo-surface ends abruptly northward where it is cut by the ESE-striking Loutraki fault. This fault shows the typical morphology of an active normal fault escarpment: overall upward convex-shaped profile (Wallace 1978), wineglass valleys, and triangular facets (Figs. 5, 6). The $\sim 4^{\circ}$ southward tilt of the paleosurface is highlighted by a reverse sense of drainage in the windgap shown on Fig. 5a. The overall morphology can be simply interpreted as the result of footwall uplift and southward

130 tilt associated with the northward dipping Loutraki normal fault. Topographic profiles 131 crossing the Loutraki fault escarpment (profiles L1, L2 and L3 in Fig. 6), show two benches 132 that represent either several parallel migrating faults (i.e. "paleo" scarps) or interaction 133 between footwall uplift and notching due to headward erosion from high stand sea levels. In 134 either case, the location of the present-day active normal fault would be at the base of the 135 escarpment (Figs. 5, 6). It would account for the topography (footwall uplift southward of the 136 fault/ hanging wall subsidence northward of the fault) and the occurrence of incision 137 southward of the fault, compatible with footwall uplift (Fig. 5). A more complex fault 138 geometry occurs east of the Loutraki Fault. Here, we observed in the field (1) a normal F1 139 fault plan between Mesozoic limestones and old alluvial fan deposits $\left(\mathrm{N} 120^{\circ} 55^{\circ} \mathrm{N} 85^{\circ} \mathrm{E}, \mathrm{FP}\right.$ 140 on Fig. 5); (2) incision to the north of F1 within an old alluvial fan deposits. This incised 141 alluvial fan is bounded to the north by an E-striking slope break. We interpret this slope break 142 as resulting from an additional normal fault (F2 on L1 profile of Fig. 6), which controls the 143 uplift of the old alluvial fan deposits and the subsidence in the Amvrakikos Gulf. Thus, to the 
144 east of the Loutraki Fault, deformation could have migrated northward onto a younger fault

145 segment F2, owing to the growing depression caused by rifting in the Amvrakikos Gulf.

146 South of the Loutraki fault, the uplifted paleo-surface is bounded to the east by pronounced

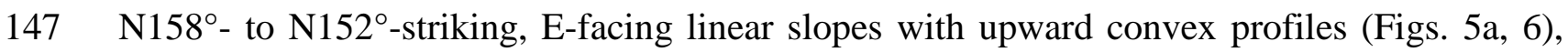

148 such kind of escarpments are typically associated to normal fault in the U.S Basin and Range

149 province (Wallace 1978). These linear E-facing escarpments are carved within easy erodible

150 gypsum along the Katouna valley. The preservation of such escarpments in gypsum

151 demonstrates that faults have a high level of activity. In addition, the fairly planar geometry of

152 these escarpments indicates they correspond to the exhumation of normal fault plans.

153 Moreover, the British Petroleum Co Ltd (1971) mapped an east dipping normal fault in the

154 Katouna valley. According to our geological cross-section (Fig. 7), a fault with a vertical slip

155 component is actually necessary in the Katouna valley to account for the anomalous contact

156 between Triassic gypsum and Early Cretaceous limestones in the Katouna valley. Our cross-

157 section also intersects the southern termination of a northern segment (Fig 5). Upper Pliocene-

158 Early Pleistocene lacustrine deposits are uplifted along one of these faults (profile K2 on Fig.

159 6, Fig. 7). The inferred total vertical throw across the fault segments reaches $750 \mathrm{~m}(\sim 300 \mathrm{~m}$ of

160 footwall uplift, $\sim 450 \mathrm{~m}$ of hanging wall subsidence). The steep dip proposed in our cross-

161 section follows the linear fault traces at the surface (Fig. 5). A steep east-dipping normal fault

162 agrees with the occurrence of micro-seismicity at $20 \mathrm{~km}$ depth, slightly east of the Katouna

163 valley (Hatzfeld et al. 1995). We thus interpret the Katouna valley as a structural landscape,

164 the morphology being controlled by active steep eastward dipping normal fault segments.

165 Comparing the Katouna valley with the nearby Amphilochia valley to the east suggests this 166 major valley is quite different (Fig. 5). Previous studies (Vassilakis et al. 2011) and geological 167 maps (British Petroleum Co Ltd, 1971; Institute of Geology and Mineral Exploration, IGME, 168 1987), have proposed this valley to be an active left-lateral strike-slip fault zone. First of all, 
along the Amphilochia valley, the topography follows directly the geological folding (i.e., the

170 valley bottom coincides with a syncline axis, Fig. 7), suggesting that a large part of this 171 depression could be inherited from Tertiary folding. The vertical throw of the hypothetic fault

172 is small as the same layer is cropping out on both side of the reported fault (Fig. 7), and the 173 concave regraded slopes of the valley (profile K3, Fig. 6) do not suggest any active vertical 174 component for the fault (Wallace 1978). This could be compatible with a pure strike-slip fault 175 running in the middle of the valley bottom (as suggested by the geological map of the Institute 176 of Geology and Mineral Exploration, IGME, 1987), and covered by constantly aggrading 177 Holocene deposits. However, the lack of benches and elongated small depressions along the 178 possible fault trace within the hard limestones on the northern Amphilochia valley do not 179 agree with any active strike-slip fault along the Amphilochia valley. Therefore, we propose 180 that most of the northern KSF deformation is presently accommodated along the Katouna 181 valley.

\subsection{Evidence for active left-lateral motion along the KSF}

183 In the previous section, we show that the total escarpment height of the Loutraki normal fault is $\sim 700 \mathrm{~m}$ (Fig. 6). As the KSF, eastern border of the uplifted paleo-surface, is linked to the Loutraki fault in its northern termination, the KSF escarpment height is directly controlled by the Loutraki escapement height in its northernmost section. However, far enough from the

187 Loutraki fault, at the west of the Amvrakia lake, the altitude of the uplifted paleo-surface 188 becomes stationary at about $~ 300$-m high (Fig. 5), suggesting that this area is no longer 189 influenced by the Loutraki footwall uplift and tilt (Figs. 5, 6). Then, in this area, the uplifted 190 paleo-surface would be only due to the KSF footwall uplift $(\sim 300 \mathrm{~m})$. The conspicuous 191 difference in footwall uplift (with 2 to 1 ratio) between the Loutraki normal fault and the

192 Katouna valley faults indicates that either the Loutraki fault initiated earlier or the Katouna 
valley faults are not purely normal. The second option is more likely because the KSF fault

194 segments show a typical en-echelon pattern with left stepovers systematically associated with depressions (Katouna valley, Amvrakia lake, southern Acheloos river valley, Aitoliko lagoon, Fig. 4). Along the KSF, only one right stepover occurs, and it is associated to a range in easy-

197 erodible Triassic breccias and gypsum, at the western border of the Ozeros lake (oz. on Fig.

198 4). These observations are thus compatible with left-releasing stepovers and right-restraining

199 stepover, respectively, implying a left-lateral component along the KSF fault segments. At the right-restraining stepover location (oz. on Fig. 4), we surmise a possible low dip east verging thrust to account for the range west of the Ozeros lake depression (flexural depression due to a possible east verging thrust). Accounting for this oblique-slip and aware of the difficulty to connect the same objects across this type of fault, we concentrate our observations on local drainage crossing the KSF to retrieve evidence for left-lateral offsets. As it may be expected on an oblique-slipping fault, we did not find any conspicuous dogleg offset. Nevertheless, we identified several potential offsets along the southern fault segment of the Katouna valley where 8 streams are left-laterally diverted with finite displacements ranging from 5 to $50 \mathrm{~m}$ 208 (five of these stream offsets are shown on Fig. 8). One could argue that such stream 209 diversions may result from the random meanderings of the downstream channels on top of the 210 young alluvial fans located in the hangingwall block. However, small diverted streams are 211 observed on the northern termination of the southern fault segment of the Katouna valley, 212 where the fault displacement and escarpment disappear (Fig. 8a). Here the stream channels 213 incise in similar alluvial material on both sides of the KSF. Thus, these small diverted streams 214 are more likely to preserve true left-lateral fault displacements (Fig. 8a). Interestingly, they 215 appear to record some $\sim 10 \mathrm{~m}$ of left-lateral offset while larger streams display higher amounts 216 of left-lateral offset, the maximum value being $\sim 50 \mathrm{~m}$ (Fig. $8 \mathrm{c}$ ). It must be stressed that, as has 
217 been reported for the San Andreas Fault, many streams do not display any offset or can even 218 show right-lateral diversions (e.g., Gaudemer et al. 1989).

219 We also found some evidence of active strike-slip motion in the Stamna area, to the south of 220 the Katouna valley (Sta on Fig. 4a). Here, a N162 ${ }^{\circ}$-striking linear depression extends $\sim 5.5$ $221 \mathrm{~km}$ from the southwesternmost tip of the Trichonis depression to the Stamna village (Fig. 9). 222 This linear depression is carved within Plio-Pleistocene deposits, close to the limit with 223 Triassic breccias (Fig.4b), forming a 300-400 m wide, $\sim 10 \mathrm{~m}$ deep, flat bottomed, perched 224 valley, with similar heights of both western and eastern valley divides (Fig. 9). This perched 225 valley is drained by small streams only, and thus appears oversized (Fig. 10). This peculiar 226 feature is interpreted as due to the differential erosion of the sheared zone along an active $227 \mathrm{~N} 162^{\circ}$-striking strike-slip fault. This would account for the dominant linear drainage network 228 (Fig. 10) and the small streams flowing nearly orthogonally toward the perched valley, whereas the major natural draining outlet of the area is the Aitoliko lagoon (Figs. 9, 10). This suggests these small streams result from headward erosion associated with the tectonically 231 controlled perched valley. Interestingly, a small fault plane (N162 $65^{\circ} \mathrm{W} 13^{\circ} \mathrm{S}$, Fig. 11) 232 within Plio-Pleistocene deposits has been observed along the perched valley. The absence of 233 morphological evidence for active vertical component (i.e., no fault escarpment and same 234 height for perched valley divides), as well as the sub-horizontal slickensides of the fault plane 235 (Fig. 11) suggest a nearly pure strike-slip faulting along the Stamna segment. Unfortunately, 236 drainage network does not allow characterizing the sense of slip along the Stamna segment 237 (i.e., no clear left-lateral offset stream, Fig. 10). We can only propose a left-lateral slip for the 238 Stamna segment based on the overall KSF segments geometry (i.e., left-releasing stepovers 239 north and south of the Stamna segment, Fig. 9). Moreover, the left-lateral slip indicated by the 240 slickensides on the observed fault plane also agrees with left lateral motion (Fig. 11). 
Overall, the KSF thus depicts a 65-km-long NNW-striking active fault system extending from

242 the Patras Gulf to the Amvrakikos Gulf (Figs. 3, 4). KSF segments are typically $~ 10$ km-long.

243 Motion along the KSF evolves from left-lateral transtension on faults segments striking

$244 \mathrm{~N} 158^{\circ}-\mathrm{N} 152^{\circ}$ (Katouna area) to nearly pure left-lateral strike-slip on segments striking N162 ${ }^{\circ}$ 245 (Stamna area).

\subsection{Internal deformation within Akarnania? Investigating the $\mathrm{N}$-striking} Akarnania thrusts

External Hellenides orogen in Akarnania led to the formation of both $\mathrm{W}$ - and E-verging, N-

249 striking thrusts during the Neogene (Clews 1989; Underhill 1989)). These N-striking thrusts 250 are located to the west of the present KSF and separate Mesozoic limestones in the 251 hangingwalls from Tertiary molasses and flysch basins in the footwalls (Paleros, Mytikas, and 252 Astakos thrusts, Fig. 4). Post-Pliocene out-of-sequence reactivation of these thrusts have been 253 proposed (Clews 1989), as well as present-day normal faulting along the Astakos thrust 254 (Vassilakis et al. 2006). However, we report below some geologic, tectonic, and geomorphic 255 observations suggesting these Cenozoic thrusts are no longer active.

256 The contact between Ionian Mesozoic limestones thrusting eastward over Oligocene flysch 257 deposits is exposed to the south of the Astakos fault (Fig. 12a). Nevertheless, this E-verging 258 thrust is seen sealed by strongly calcite-cemented breccias (SBr. on Fig. 12a). These breccias 259 consist of cryoclastic angular elements with no clay matrix, which result from limestone 260 bedrock degradation during a cold climate. Such kind of strongly calcite-cemented breccias 261 are attributed to the Middle Pleistocene ( $600 \mathrm{ka}$, Sorel 1976). The fault sealing indicates that 262 no tectonic activity has occurred along the Astakos thrust for the last $~ 600$ ka. Farther north, 263 along this Astakos thrust, destroyed houses of the Paleo Karaiskakis village stand on the 264 Oligocene flysch deposits. At this place, a roughly N-striking, curved scarp points to the limit 
265 between the Ionian limestones and their screes, overlying the flysch deposits and hiding the 266 Astakos thrust contact (Fig. 12b). We interpret this curved scarp trace as a landslide head scar, 267 caused by gravitational processes that occurred within the flysch deposits and destroyed the 268 Paleo Karaiskakis village. The N-striking normal fault reported close to Astakos village 269 (Vassilakis et al. 2011) should correspond to similar gravitational processes. Therefore, in the 270 Astakos area, there is no evidence for tectonic activity either on the Astakos thrust or on N271 striking normal faults.

272 Strongly cemented slope breccias are also observed sealing the W-verging Paleros thrust front 273 (Fig. 12c). At some places, a discontinuous linear cliff highlights the contact between the 274 Ionian Mesozoic limestones, covered by strongly cemented breccias, and the more erodible 275 Miocene molasses deposits. This linear feature could be interpreted as an active normal fault 276 scarp. However, the along-strike strong variation of cliff height (red arrows on Fig.12c) 277 results more likely from differential erosion between Miocene sandy molasses and the 278 limestone rocks (Ionian Mesozoic and Quaternary slope breccias). This observation also 279 agrees with a lack of tectonic activity along the Paleros thrust. Similar conclusions can be 280 derived from observations along the Mytikas E-verging thrust.

281 All our geomorphic/tectonic observations in central Akarnania are summarized in a 282 conceptual sketch (Fig. 13). They show the N-striking Akarnania thrusts presently inactive, 283 and some apparently normal fault scarp resulting from gravitational processes and/or gully 284 differential erosion. As there is no evidence for significant active deformation in Akarnania 285 west of the KSF, we consider Akarnania as a rigid block. 


\section{Cosmic Ray Exposure (CRE) dating of an offset alluvial fan}

\section{along the KSF and minimum geological slip-rate}

Along the Katouna valley, the normal component of slip of the KSF cannot be constrained because the hangingwall displays recent alluvial or colluvial deposits that are not present in the footwall block. In contrast, the horizontal component of slip may be estimated thanks to diverted streams that appear to record the left-lateral component of the KSF (See previous section). The smaller streams show two convincing offsets of $\sim 10 \mathrm{~m}$ (Fig. $8 \mathrm{a}$ ). We are not aware of any data that could provide an estimate of the age of these streams. They could correspond to the mid-Holocene incision (5-7 ka), which is subsequent to the sapropel sedimentation in the Mediterranean domain (Gasse et al. 2015). Such an assumption would lead to a maximum slip rate of $\sim 2 \mathrm{~mm} / \mathrm{a}$. However, these smaller incisions might also correspond to younger climatic episodes, or even to historical ones. Hence, they cannot be used to derive accurate slip rates. Thus, we focused on the largest stream offsets as they may provide, due to their deeper incisions within the proximal part of the younger alluvial fans, more favorable conditions for radiometric dating.

\subsection{Description and location of the sampling site}

The site selected to perform Cosmic Ray Exposure (CRE) dating is the largest left-laterally offset stream where the upslope part of a displaced alluvial fan forms a shutter ridge facing a ravine incised into the footwall escarpment of the southern Katouna fault (Fig. 14). To the east of the fault, the downstream prolongation of this ravine forms a $\sim 6 \mathrm{~m}$-incised gully in the alluvial fan (Fig. 14c). The gully is left-laterally offset by $54 \pm 4 \mathrm{~m}$ (Fig. 14b). As alluvial fan aggradation and abandonment predate gully incision, the age of the alluvial fan abandonment provides the upper bound age for the gully incision. Dating this abandonment using in situ- 
produced cosmogenic nuclides should provide an estimate of the minimum geological

310 horizontal slip-rate of the Katouna fault. The CRE dating method is widely used to constrain

311 cosmic ray exposure duration of geomorphic features. Applied to an alluvial fan, the CRE age

312 reflects the abandonment age of the alluvial surface after its aggradation and before its

313 subsequent incision.

314 The sampling site is a natural outcrop carved within the offset alluvial fan material, where the

315 external part of an active meander forms an active cliff (Fig. 15, sampling site location

316 referred as $\mathrm{P}$ on Fig. 14b). Remnants of historical-time flood deposits within the bottom of the

317 gully incision indicate that the outcrop is frequently rejuvenated and has consequently not

318 been long exposed. As the top of the alluvial fan is covered by $\sim 1.20 \mathrm{~m}$-thick shard bearing,

319 historical colluvium, we sampled $\sim 5.30 \mathrm{~m}$-high depth profiles without collecting any surface

320 sample (Fig. 15). The alluvial material crops out on a 4.10-m section and consists of proximal

321 debris flow with sub-angular to sub-rounded elements (gravels and cobbles), comprising

322 reworked Mesozoic limestones and flints from the Ionian unit serie. Due to the nature of these

323 elements, we sampled along two depth profiles: one including only cherts and the other only

324 carbonates to perform concentration measurements of in situ-produced ${ }^{10} \mathrm{Be}$ and ${ }^{36} \mathrm{Cl}$

325 cosmogenic nuclides, respectively. Sample preparations were performed at CEREGE (Aix-en-

326 Provence) and AMS measurements at the French national AMS facility ASTER (CEREGE,

327 Aix-en-Provence) (detailed procedures are given in Supplementary Material).

\subsection{CRE dating results and minimum geological slip-rate}

329 Cosmogenic nuclide concentrations measured as a function of depth are controlled by three

330 parameters: (1) the exposure duration to cosmic rays at the sampling depth; (2) the denudation

331 rate affecting the sampled surface and, (3) the inherited cosmogenic nuclide concentration

332 accumulated during a pre-exposure history and/or the transport from the source region 
(inheritance). In case of homogeneous inheritance, the in-situ produced cosmogenic nuclide

334 concentrations decrease exponentially with depth and tend to an asymptotic value of zero (no

335 inheritance) or non-zero, corresponding to the amount of the measured concentration that is

336 inherited (Siame et al. 2004; Braucher et al. 2009). In this case, the three unknown parameters

337 can be determined from the modeling of measured depth-profile concentrations.

338 The presented results do not show such a distribution (Fig. 16). Measured ${ }^{10} \mathrm{Be}$ and ${ }^{36} \mathrm{Cl}$

339 concentrations are both scattered and do not exhibit any exponential decrease with depth,

340 indicating most likely that the samples were deposited in the alluvial fan with a highly

341 variable inherited component. In addition, ${ }^{36} \mathrm{Cl}$ surface in situ-production rate is significantly

342 higher than ${ }^{10} \mathrm{Be}$ surface in situ-production rate (Nishiizumi et al. 2007; Schimmelpfennig et

343 al. 2009). Therefore, measured ${ }^{36} \mathrm{Cl}$ concentrations significantly lower than ${ }^{10} \mathrm{Be}$

344 concentrations along the profile may indicate that chert samples were exposed to cosmic ray

345 prior to their deposition in the alluvial fan for a much longer time-period than carbonate

346 samples, leading to a more concentrated ${ }^{10} \mathrm{Be}$ inherited component in cherts than the ${ }^{36} \mathrm{Cl}$

347 inherited component in carbonates. On the other hand, measured in situ-produced ${ }^{10} \mathrm{Be}$

348 concentrations largely exceed the maximum allowed ${ }^{10} \mathrm{Be}$ concentration that corresponds to

349 infinite exposure duration on a non-eroding surface (Suppl. Material, Table S1). This then

350 suggests a possible adsorption of ${ }^{10} \mathrm{Be}$ at the surface within amorphous silica as recently

351 evidenced (Zerathe et al. 2013). For all these reasons, measured ${ }^{10} \mathrm{Be}$ concentrations in cherts

352 are not suitable for dating the alluvial fan abandonment age.

353 Nevertheless, the ${ }^{10} \mathrm{Be}$ concentrations accumulated during an assumed infinite pre-exposure

354 duration correspond to the steady-state ${ }^{10} \mathrm{Be}$ concentrations that only depend on the

355 denudation rate. They give therefore the opportunity to calculate maximum denudation rates

$356\left(\varepsilon_{\max }\right)$ (Suppl. Material, Table S2). As source regions for cherts should be the Ionian zone

357 (Suppl. Material, Fig. S1), a possible explanation to account for such high inheritance would 
be that these cherts have been spread as residual elements onto the Katouna paleo-surface that eroded most of the Ionian thrust sheet, up to the Triassic breccias. This paleo-surface is presently eroded by the upstream catchments of the alluvial fan (Fig. 14a) allowing cherts to be transported and aggraded downstream in the alluvial fan. The maximum denudation rates $\left(\varepsilon_{\max }\right)$ determined on cherts would thus correspond to the denudation of the Katouna paleosurface. Most of these calculated $\varepsilon_{\max }$ are lower than $5 \mathrm{~m} / \mathrm{Ma}$ (Suppl. Material, Table S2), suggesting a relatively low denudation rates for the region.

The carbonate ${ }^{36} \mathrm{Cl}$ concentrations, ranging from $1.10^{5}$ at/gr. to $2.5 .10^{5}$ at/gr. (Fig. 16) are less scattered than those of ${ }^{10} \mathrm{Be}$. Carbonate elements, sampled in the same alluvial fan as the 367 cherts, thus carry a less complicated pre-exposure history. Hence, it allows modeling the in368 situ produced ${ }^{36} \mathrm{Cl}$ concentrations, and then to estimate an abandonment age for the alluvial 369 fan. As the upper $1.20 \mathrm{~m}$ of the depth profile consists of historical colluviums, we consider that the initial fan surface is located at $1.20 \mathrm{~m}$ depth below the surface. Consequently, the 371 CRE age modeling of the alluvial deposits was performed on the carbonate samples below $3721.20 \mathrm{~m}$ depth (Fig. 17b). The scattering of the measured ${ }^{36} \mathrm{Cl}$ concentrations and the 373 occurrence of high ${ }^{36} \mathrm{Cl}$ concentrations in the deepest part of the profile suggest variable 374 inherited ${ }^{36} \mathrm{Cl}$ concentration in the carbonate samples, that do not permit to run a simple CRE age modeling assuming an homogeneous inheritance. In case of variable inheritance, a 376 rejuvenation depth profile analysis (Le Dortz et al. 2012) allows providing a maximum 377 abandonment age for the fan surface. Assuming a negligible denudation rate as estimated 378 from the ${ }^{10} \mathrm{Be}$ concentrations (Suppl. Material, Table S2), this rejuvenation analysis provides 379 a maximum exposure duration (i.e., abandonment age) for the alluvial fan surface of $\sim 10 \mathrm{ka}$ 380 (Fig. 17b, Table 2). Then, the sensitivity of this abandonment age has been tested for different 381 denudation rates of 5, 20, and $30 \mathrm{~m} / \mathrm{Ma}$ (Table 3), yielding to maximum exposure durations 382 ranging between 10.2 and $11.7 \mathrm{ka}$. Therefore, a maximum abandonment age for the alluvial 
fan surface of 10-12 ka is retained. Considering an age of $\sim 2 \mathrm{ka}$ for the $1.20 \mathrm{~m}$ thick historical

384 colluviums and a maximum abandonment age for the alluvial fan surface of 10-12 ka, this 385 leads to a maximum alluvial fan aggradation duration of 12-14 ka, i.e., approximately coeval 386 with the transition between the Marine Isotopic Stages 2 and 1. This suggests that the fan 387 aggraded at most, after the Last Glacial Maximum, close to the beginning of Holocene.

388 Finally, as alluvial fan aggradation and abandonment predate the inception of gully incision, it 389 can thus only be concluded that incision started at most 12-14 ka ago. Because only a 390 maximum age for the fan incision can be determined, only the minimum slip-rate of the KSF 391 can be estimated, using the minimum value of the left-lateral offset. The stream incision offset 392 of at least $50 \mathrm{~m}$ (Fig. 14b) that started at most 12-14 ka ago yields an estimated Holocene 393 minimum left-lateral slip rate bracketed between 3.6 and $4.2 \mathrm{~mm} . \mathrm{yr}^{-1}\left(\sim 4 \mathrm{~mm} . \mathrm{yr}^{-1}\right)$.

394 4. Active kinematics of Western Greece from GPS data

395 We used the GPS data compilation of Perouse et al. (2012) and added new data. Original GPS 396 vectors (Hollenstein et al. 2008; Floyd et al. 2010; GPSscope permanent GPS network) and new data (Briole 2013) have been rotated into a self-consistent Eurasian reference frame. GPS velocities in Akarnania can be minimized by a single rigid rotation defining an 399 Akarnania fixed reference frame (Fig. 18). The absence of a gradient in the fault parallel 400 component of velocity vectors across the KSF attests to localized deformation implying either 401 low elastic coupling (i.e., superficial elastic locking depth) or/and creeping behavior. 402 However, residuals exist in the Ionian Islands. These trend parallel to the Kefalonia fault, and 403 are NE directed (Fig. 18). To account for this measured GPS velocity field, we interpret the 404 Ionian Islands and Akarnania as moving as a single rigid block: the IAB (Ionian Islands- 
Akarnania Block). Then, the NE directed residuals in the Ionian Islands would result from

406 interseismic elastic loading along the dextral Kefalonia fault.

407 The northern and northeastern boundaries of the IAB would be the Amvrakikos Gulf and the 408 Katouna valley fault (northern KSF), respectively (Fig. 19). According to GPS vectors on Fig. 40918 , these structures accommodate IAB/continental Greece relative motion as $\sim 10 \mathrm{~mm} . \mathrm{yr}^{-1}$ of $410 \mathrm{~N}-\mathrm{S}$ extension across the Amvrakikos Gulf and approximately the same amount of left-lateral 411 motion along the Katouna fault, a result in agreement with the Vassilakis et al. (2011) 412 estimation. The actual motion along the Katouna fault (northern KSF) is transtensional: 11 $413 \mathrm{~mm} \cdot \mathrm{yr}^{-1}$ of fault-parallel left-lateral motion and $\sim 3 \mathrm{~mm} \cdot \mathrm{yr}^{-1}$ of fault perpendicular extension 414 (Fig. 19). The western boundary of the IAB, that accommodates the relative motion between 415 IAB and the Apulian platform, is the dextral Kefalonia fault. Determining the Kefalonia Fault 416 slip-rate is not straightforward as no GPS vectors are available west of the fault, which is an 417 offshore domain (Fig. 18). However, the triple junction occurrence between the Apulian 418 platform, the Continental Greece and the IAB (Fig. 19) enables a slip-rate assessment for the 419 Kefalonia fault: as the Apulian platform converges toward continental Greece at $\sim 5{\mathrm{~mm} . \mathrm{yr}^{-1}}^{-1}$ 420 (e.g., Perouse et al. 2012), and considering $\sim 10 \mathrm{~mm} \cdot \mathrm{yr}^{-1}$ of N-S extension between IAB and 421 continental Greece, it would imply a Kefalonia fault slip-rate of $\sim 15$ mm.yr ${ }^{-1}$ (Fig. 19). 422 Precision of this estimation, which gives an order of magnitude for the Kefalonia fault sliprate, has to be improved in the future accounting elastic coupling processes.

424 Finally, the Southern Trichonis region belongs neither to continental Greece, nor to the IAB 425 in contrast to what has previously been proposed (Vassilakis et al. 2011). Indeed, this region 426 moves at $\sim 6 \mathrm{~mm} \cdot \mathrm{yr}^{-1}$ toward the $\mathrm{NW}$ relative to the IAB (Fig. 18). This motion is accommodated by $\sim 6 \mathrm{~mm} . \mathrm{yr}^{-1}$ of pure left-lateral strike-slip along the Stamna fault (southern 428 KSF), and $\sim 4$ mm. $\mathrm{yr}^{-1}$ of N-S extension across the Trichonis graben (Figs. 18, 19). The 429 Trichonis graben is located at the junction between the northern KSF (Katouna area) and the 
southern KSF (Stamna area). The $\sim 4 \mathrm{~mm} . \mathrm{yr}^{-1}$ of N-S extension across the Trichonis graben would thus account for the left-lateral slip-rate difference between the Katouna segment $(\sim 11$ mm. $\mathrm{yr}^{-1}$ of left-lateral motion) and the Stamna segment $\left(\sim 6 \mathrm{~mm} \cdot \mathrm{yr}^{-1}\right)$. Motions in southern Trichonis increase eastward, reaching values close to those of continental Greece, resulting in insignificant relative motion between the eastern tip of the southern Trichonis and the western Gulf of Corinth (Fig. 18).

\section{Discussion}

\subsection{A creeping behavior for the KSF ?}

High slip-rate on the KSF (> $4 \mathrm{~mm} \cdot \mathrm{yr}^{-1}$ according to geological data, possibly up to $11 \mathrm{~mm} \cdot \mathrm{yr}^{-}$ ${ }^{1}$ according to GPS) contrasts with the subdued morphological evidence for tectonic activity (this study) and the relatively low level of historical (Papazachos and Papazachou 1997) and instrumental seismicity (Fig. 2). Indeed, if mesoscale deformation is well expressed along the KSF (fault valley, rectilinear convex-shaped upward escarpments, en-échelon fault pattern), the small scale deformation is nearly missing. The fault shows no clear "earthquake-related" scarps, and scarce well developed dogleg stream offsets. This could suggest that the shortterm tectonic landscape is not preserved due to the high level of anthropogenic activity along the KSF. Nevertheless, a stick-slip behavior on a fast slipping KSF should preserve at least some earthquake-related landforms even with high anthropogenic activity. An entirely locked, $11 \mathrm{~mm} . \mathrm{yr}^{-1}$-slipping fault (see previous section) would produce a $\sim \mathrm{M}_{\mathrm{w}} 7$ earthquake in average at least each 500 years with a 1-2 m-high scarp, resulting from the expected $3 \mathrm{~mm} . \mathrm{yr}^{-}$ ${ }^{1}$ of extension across the northern KSF. Such a scenario is very unlikely, because such a scarp would not be entirely erased everywhere in some hundreds of years and further, there should be some evidence of large earthquakes in the historical seismicity records. Even assuming that 
453 a high percentage of the GPS-derived deformation is transitory and that the average KSF slip

454 rate is closer to the geological minimum estimate, it would not change significantly these 455 conclusions. Consequently, a high percentage of the fault displacement should be 456 accommodated by creep slip. This creep should increase significantly the average return 457 period between two subsequent seismic events as well as lower their magnitudes. Less 458 frequent earthquakes with smaller surface displacements may explain why the small-scale 459 seismic landform is not preserved. Creeping, which may be favored by the gypsum-breccias 460 of the KSF bedrock, is further suggested by the absence of gradient in the fault parallel component of velocity GPS vectors across the KSF (Fig. 18). It also agrees with the large deficit of seismic moment rate compared to geodetic moment rate in Akarnania (Chousianitis et al. 2015).

\subsection{Ionian Islands-Akarnania Block (IAB) geometry and kinematics}

465 East of the Kefalonia fault that connects the Apulian collision front to the Hellenic subduction 466 front, we show that deformation in the overriding plate domain is localized along the KSF and 467 the Amvrakikos gulf as no significant deformation occurs along the Neogene N-striking 468 thrusts of Akarnania, located west of the KSF. It delineates a Ionian-Akarnania block (IAB, 469 Fig. 19).

470 The NNW- striking KSF, northeast boundary of the IAB, terminates northward onto the ESE471 striking Loutraki fault. Regionally, the Loutraki fault could belong to an ESE-striking 472 Amvrakikos Gulf half-graben system, with a northward dipping master fault (Fig. 3). Indeed, 473 E-W active fault segments have been imaged at the western termination of the Gulf (sparker 474 seismic-reflection profiles, Anastasakis et al. 2007). The submerged morphology, the 475 southward flexure and the absence of clear E-W active normal fault trace on the northern side 476 of the Amvrakikos Gulf suggest a half-graben geometry. However, the eastern submerged 
part of the Gulf has not been imaged yet, so we cannot clearly constrain what is controlling the subsidence east the Loutraki fault. The ESE-striking Amvrakikos Gulf half-graben system we propose would represent the northern boundary of the IAB. The western and southwestern boundaries of the IAB would be the Kefalonia fault and the Hellenic subduction front respectively (Fig. 19). Finally, the IAB southeastern boundary might be located in the NW Peloponnesus, along the right-lateral Achaia-Elia fault (Fig. 19) associated to the $2008 \mathrm{M}_{\mathrm{w}} 6.4$ Movri earthquake (Serpetsidaki et al. 2014). This Achaia-Elia fault zone should accommodate the relative motion between the IAB and the Peloponnesus. The trenchward motions of these two blocks are $\sim 10 \mathrm{~mm} / \mathrm{yr}$ for the IAB (constrained by the KSF rate) and some $\sim 15 \mathrm{~mm} / \mathrm{yr}$ for the Peloponnesus (constrained by the opening rate of the Corinth Rift), respectively. Consequently the right-lateral rate of the Achaia-Elia fault zone should be $\sim 5 \mathrm{~mm} / \mathrm{yr}$. In our model, the Gulf of Patras graben system should correspond to a triple junction between the western tip of the Corinth Rift, the KSF and the Achaia-Elia Fault zone (Fig. 19). In more details, the triple junction zone between Peloponnesus, Continental Greece and our determined IAB could actually be a diffuse zone spread over the Nafpaktos basin (basin linking the western tip of the Corinth rift to the Patras gulf), as proposed by Beckers et al. (2015), based on a submarine active faults study of the region. Thus, kinematics of the IAB fault boundaries indicates a trenchward motion, compatible with the regional Hellenic slab retreat.

At first order, the IAB geometry we propose in this paper shares several similarities with the Akarnania "fragment" proposed by Vassilakis et al. (2011). However, our study delineates the NNW-striking Stamna fault segment as the south-eastern prolongation of the Katouna fault, indicating the southern KSF fault system connects directly with the Patras Gulf, contrasting with a Amphilochia valley-Trichonis graben-Gulf of Corinth faults network (Vassilakis et al. 2011). Consequently, in our model, the opening of the Trichonis graben, located at the 
junction between the Katouna and the Stamna faults, accommodates the left-lateral slip-rate

503 difference between the northern and southern KSF (Fig. 18, 19). Finally, despite a high

504 seismic activity along a NW trend connecting the western tip of the Corinth rift to the

505 Trichonis graben (Fig. 2, Evangelidis et al. 2008; Kiratzi et al. 2008), active faulting is not

506 observed either in the morphology or from GPS data (Fig. 18). It suggests that this area,

507 seismically "crackling", could represent an incipient fault zone, not yet established (Fig. 19).

\subsection{Timing individualization of the Ionian Islands-Akarnania Block (IAB)}

509 Such a high slip rate on short surface fault segments suggests that the KSF (northeastern

510 boundary of the IAB, Fig. 19) is not yet a mature system. The direction of the KSF, collinear

511 with the NNW-striking Ionian thrust formed during Hellenides orogen (Figs. 3, 4), suggests

512 structural inheritance. However, in the Katouna area, our results show that the KSF is a steep

513 fault, crosscutting the Ionian thrust sheet at depth (Fig. 7). The KSF could thus be a

514 neoformed fault, but whose direction has been controlled by the Hellenides orogen fabric.

515 As the KSF is directly connected to the Loutraki fault, initiation of the Loutraki

516 fault/Amvrakikos half-graben and the KSF should be synchronous. According to the

517 sedimentological record of Amvrakikos Gulf series, regional subsidence in the Amvrakikos

518 Gulf would have initiated at least since MIS 8 (245-300 ka, Anastasakis et al. 2007). In

519 addition, due to the triple junction between Continental Greece, the Apulian-Ionian micro-

520 plate and the IAB (Fig. 19), extension initiation across the Amvrakikos Gulf may be

521 contemporary or younger than dextral initiation along the Kefalonia fault. Dextral shear along

522 the Kefalonia fault, an inherited normal fault of the Apulian platform (Sorel 1976), would

523 have initiated ca. 1.5-1.3 Ma (Sorel 1976; Cushing 1985; Nielsen 2003). The present-day

524 Loutraki fault has an escarpment height of $\sim 700 \mathrm{~m}$ (Fig. 6). For comparison, the East Helike

525 fault, a northward dipping active normal fault of the Corinth Rift system having a $\sim 800 \mathrm{~m}$ 
escarpment height $(1600 \mathrm{~m}$ of total vertical throw, $\sim 800$ of footwall uplift, $\sim 800$ of

527 hangingwall subsidence), and which extension rate evolution is well constrained, would have 528 initiated at 700-800 ka (McNeill and Collier 2004; Ford et al. 2013). However, as we have no 529 constrain about the Loutraki fault extension rate evolution, a reasonable age initiation for the 530 Loutraki fault/Amvrakikos Gulf system (and consequently its connected KSF) can thus be 531 bracketed between $\sim 1.5 \mathrm{Ma}$ and $300 \mathrm{ka}$. Finally, our observations suggest that no more 532 internal E-W compression occurs in Akarnania since $~ 600 \mathrm{ka}$ since the N-striking Astakos 533 thrust is sealed by Middle Pleistocene slope breccia (Figs. 12, 13). All these age constraints 534 and faults geometries in Akarnania are compatible with a change from E-W compressional 535 stress regime to a near N-S horizontal $\sigma 3$ axis during the Pleistocene, leading to the 536 progressive individualization and trenchward motion of the IAB. Hence, initiation of the IAB 537 individualization could be coeval with the Corinth rifting phase 2 or $3(\sim 1.7$ Ma to $~ 700 \mathrm{ka}$, 538 and $\sim 700$ ka to present-day, respectively, Ford et al. 2013). The right-lateral Achaia-Elia fault, 539 potential southeastern boundary of the IAB, is considered juvenile because no coseismic 540 surface rupture occurred during the $2008 \mathrm{M}_{\mathrm{w}} 6.4$ Movri earthquake (Feng et al. 2010) and no 541 morphological evidence attests long-term fault activity (Stiros et al. 2013).

\section{6. Conclusion}

543 An accurate mapping of active and inactive fault traces, new multi-scale geomorphologic and 544 tectonic observations and a geodetic study provide evidence for active normal and left-lateral 545 faulting along the Katouna Stamna Fault (KSF), a 65-km-long NNW-striking fault system 546 connecting the Amvrakikos Gulf to the Patras Gulf. The KSF segments are typically $\sim 10 \mathrm{~km}-$ 547 long. We further show that the N-striking Cenozoic Hellenides thrusts, located west of the 548 KSF in Akarnania, are no longer active, by either field observation or GPS data. It results that 
the transition from subduction to collision in Western Greece is accommodated in the

550 overriding plate by the individualization of a Ionian Island-Akarnania block (IAB, Fig. 19).

551 The KSF, that we interpret as a neoformed immature fault system, but which strike is likely to

552 be inherited from the Hellenides orogen, forms presently the northeastern boundary of the

553 IAB. The northern KSF accommodates IAB motion relative to continental Greece by active

554 left-lateral transtension along the Katouna valley. The southern KSF accommodates relative

555 motion between the IAB and the southern Trichonis Lake region by left-lateral slip along the 556 Stamna fault. The KSF slip-rate is high: at least $4 \mathrm{~mm}_{\mathrm{yr}}{ }^{-1}$ of geological slip-rate was 557 determined by CRE dating on the Katouna valley segment. GPS data shows $\sim 11 \mathrm{~mm} . \mathrm{yr}^{-1}$ and $558 \sim 6$ mm. $\mathrm{yr}^{-1}$ of left-lateral slip-rate along the northern KSF (Katouna segments) and the 559 southern KSF (Stamna segments), respectively. We suggest the localized strain and high slip560 rate along the KSF should be dominantly released by aseismic creep, compatible with the 561 gypsum-breccias bedrock along the fault and the low level of seismicity. We finally propose 562 that a change from E-W compressional stress regime to a near N-S horizontal $\sigma 3$ axis would 563 have occurred in Akarnania during the Pleistocene, leading to the progressive 564 individualization and trenchward motion of the IAB from Pleistocene time (younger than $~ 1.5$ 565 Ma) to present day.

\section{Acknowledgments}

567 This research work has been funded by the Laboratoire de Géologie de l'Ecole Normale 568 Supérieure, Paris (PSL Research University). We thank V. Guillou, L. Léanni, L. Benedetti, 569 G. Aumaître, K. Keddadouche, M. Arnold, and F. Chauvet for their warm welcome and help 570 during chemistry preparation and AMS measurements at CEREGE. The AMS measurements 571 were performed at the ASTER AMS national facility (CEREGE, Aix-en-Provence), which is 572 supported by the INSU/CNRS, the ANR through the "Projets thématiques d'excellence" 
573 program for the "Equipements d'excellence" ASTER-CEREGE action, IRD and CEA. We are

574 very grateful to Mary Ford for the English syntax corrections in the manuscript, and her very 575 careful review. We thank Laurent Jolivet for valuable comments in his review. Both reviewers 576 significantly improved the final version of this work. We also thank Leigh Royden and two 577 anonymous reviewers for critical reviews of a previous version of this work. 
Anastasakis G, Piper DJW, Tziavos C (2007) Sedimentological response to neotectonics and sea-level change in a delta-fed, complex graben: Gulf of Amvrakikos, western Greece. Mar Geol 236:27-44 doi:10.1016/j.margeo.2006.09.014

Aubouin J (1959) Contribution à l'étude géologique de la Grèce septrionale; les confins de l'Epire et de la Thessalie. Annales Géologiques des pays Hélleniques 9

Braucher R, Del Castillo P, Siame L, Hidy AJ, Bourles DL (2009) Determination of both exposure time and denudation rate from an in situ-produced Be-10 depth profile: A mathematical proof of uniqueness. Model sensitivity and applications to natural cases. Quat Geochronol 4:56-67 doi:10.1016/j.quageo.2008.06.001

Braucher R, Merchel S, Borgomano J, Bourles DL (2011) Production of cosmogenic radionuclides at great depth: A multi element approach. Earth Planet Sc Lett 309:1-9 doi:10.1016/j.epsl.2011.06.036

Briole P (2013) Ground deformation across the Corinth rift from 22 years of GPS observations. Geophysical Research Abstracts 15:EGU2013-13183, EGU General Assembly, Vienna, Austria.

Briole P, Rigo A, Lyon-Caen H, Ruegg JC, Papazissi K, Mitsakaki C, Balodimou A, Veis G, Hatzfeld D, Deschamps A (2000) Active deformation of the Corinth rift, Greece: Results from repeated Global Positioning System surveys between 1990 and 1995. J Geophys Res-Sol Ea 105:25605-25625

British Petroleum Co Ltd (1971) The Geological Results of Petroleum Exploration in Western Greece. Institute of Geology and Mineral Exploration, IGME, Special Report, 10, Athens

Catalano R, Doglioni C, Merlini S (2001) On the Mesozoic Ionian Basin. Geophys J Int 144:49-64 doi:10.1046/j.0956-540X.2000.01287.x

Chamot-Rooke N, Rangin C, Le Pichon X, Dotmed working group (2005) DOTMED: A synthesis of deep marine data in the eastern Mediterranean. Mém Soc géol France $177: 64 p$

Chousianitis K, Ganas A, Evangelidis CP (2015) Strain and rotation rate patterns of mainland Greece from continuous GPS data and comparison between seismic and geodetic moment release. Journal of Geophysical Research: Solid Earth 120 doi:10.1002/2014JB011762

Clews JE (1989) Structural controls on basin evolution: Neogene to Quaternary of the Ionian zone, Western Greece. Journal of the Geological Society, London 146:447-457

Cocard M, Kahle HG, Peter Y, Geiger A, Veis G, Felekis S, Paradissis D, Billiris H (1999) New constraints on the rapid crustal motion of the Aegean region: recent results inferred from GPS measurements (1993-1998) across the West Hellenic Arc, Greece. Earth Planet Sc Lett 172:39-47

Collier REL, Dart CJ (1991) Neogene to Quaternary rifting, sedimentation and uplift in the Corinth Basin, Greece. J Geol Soc London 148:1049-1065

Cushing M (1985) Evolution structurale de la marge nord ouest Héllenique dans l'île de Levkas et ses environs (Grèce nord-occidentale). Université Paris-Sud

D'Agostino N, Avallone A, Cheloni D, D'Anastasio E, Mantenuto S, Selvaggi G (2008) Active tectonics of the Adriatic region from GPS and earthquake slip vectors. $\mathbf{J}$ Geophys Res-Sol Ea 113 
Durand V, Bouchon M, Floyd MA, Theodulidis N, Marsan D, Karabulut H, Schmittbuhl J (2014) Observation of the spread of slow deformation in Greece following the breakup of the slab. Geophysical Research Letters 41:7129-7134

Engdahl ER, van der Hilst R, Buland R (1998) Global teleseismic earthquake relocation with improved travel times and procedures for depth determination. B Seismol Soc Am 88:722-743

Evangelidis CP, Konstantinou KI, Melis NS, Charalambakis M, Stavrakakis GN (2008) Waveform relocation and focal mechanism analysis of an earthquake swarm in Trichonis Lake, western Greece. B Seismol Soc Am 98:804-811

Feng LJ, Newman AV, Farmer GT, Psimoulis P, Stiros SC (2010) Energetic rupture, coseismic and post-seismic response of the $2008 \mathrm{M}-\mathrm{W} 6.4$ Achaia-Elia Earthquake in northwestern Peloponnese, Greece: an indicator of an immature transform fault zone. Geophys J Int 183:103-110 doi:10.1111/j.1365-246X.2010.04747.x

Ferentinos G, Brooks M, Doutsos T (1985) Quaternary Tectonics in the Gulf of Patras, Western Greece. J Struct Geol 7:713-717 doi:10.1016/0191-8141(85)90146-4

Floyd MA, Billiris H, Paradissis D, Veis G, Avallone A, Briole P, McClusky S, Nocquet JM, Palamartchouk K, Parsons B, England PC (2010) A new velocity field for Greece: Implications for the kinematics and dynamics of the Aegean. J Geophys Res-Sol Ea 115

Ford M, Rohais S, Williams EA, Bourlange S, Jousselin D, Backert N, Malartre F (2013) Tectono-sedimentary evolution of the western Corinth rift (Central Greece). Basin Research 25:3-25

Gasse F, Vidal L, Van Campo E, Demory F, Develle A-L, Tachikawa K, Elias A, Bard E, Garcia M, Sonzogni C (2015) Hydroclimatic changes in northern Levant over the past 400,000 years. Quaternary Sci Rev 111:1-8

Gaudemer Y, Tapponier P, Turcotte DL (1989) River offsets across active strike-slip faults. Annales Tectonicae 3:55-76

Gosse JC, Phillips FM (2001) Terrestrial in situ cosmogenic nuclides: theory and application. Quaternary Sci Rev 20:1475-1560 doi:10.1016/S0277-3791(00)00171-2

GPSscope (permanent GPS network) supervised by Briole, P., Charade, O., and Ganas, A. online data available at http://crlab.eu.

Haslinger F, Kissling E, Ansorge J, Hatzfeld D, Papadimitriou E, Karakostas V, Makropoulos K, Kahle HG, Peter Y (1999) 3D crustal structure from local earthquake tomography around the Gulf of Arta (Ionian region, NW Greece). Tectonophysics 304:201-218 doi:10.1016/S0040-1951(98)00298-4

Hatzfeld D, Kassaras I, Panagiotopoulos D, Amorese D, Makropoulos K, Karakaisis G, Coutant O (1995) Microseimicity and strain pattern in northwestern Greece. Tectonics 14:773-785

Hollenstein C, Muller MD, Geiger A, Kahle HG (2008) Crustal motion and deformation in Greece from a decade of GPS measurements, 1993-2003. Tectonophysics 449:17-40

Institute of Geology and Mineral Exploration (IGME) (1987) Geological map of Greece, Amphilochia sheet (1:50 000).

Jolivet L, Labrousse L, Agard P, Lacombe O, Bailly V, Lecomte E, Mouthereau F, Mehl C (2010) Rifting and shallow-dipping detachments, clues from the Corinth Rift and the Aegean. Tectonophysics 483:287-304 doi:10.1016/j.tecto.2009.11.001

Karakitsios V, Rigakis N (2007) Evolution and petroleum potential of Western Greece. J Petrol Geol 30:197-218 doi:10.1111/j.1747-5457.2007.00197.x

Kiratzi A, Sokos E, Ganas A, Tselentis A, Benetatos C, Roumelioti Z, Serpetsidaki A, Andriopoulos G, Galanis O, Petrou P (2008) The April 2007 earthquake swarm near 
Lake Trichonis and implications for active tectonics in western Greece.

Tectonophysics 452:51-65 doi:10.1016/j.tecto.2008.02.009

Konstantinou KI, Melis NS, Lee SJ, Evangelidis CP, Boukouras K (2009) Rupture Process and Aftershocks Relocation of the 8 June $2008 \mathrm{M}-\mathrm{w}$ 6.4 Earthquake in Northwest Peloponnese, Western Greece. B Seismol Soc Am 99:3374-3389 doi:10.1785/0120080301

Le Dortz K, Meyer B, Sebrier M, Braucher R, Bourles D, Benedetti L, Nazari H, Foroutan M (2012) Interpreting scattered in-situ produced cosmogenic nuclide depth-profile data. Quat Geochronol 11:98-115 doi:10.1016/j.quageo.2012.02.020

Le Pichon X, Chamot-Rooke N, Lallemant S, Noomen R, Veis G (1995) Geodetic determination of the kinematics of central Greece with respect to Europe: Implications for eastern Mediterranean tectonics. J Geophys Res 100:12675-12690 doi:10.1029/95jb03170

Louvari E, Kiratzi AA, Papazachos BC (1999) The Cephalonia Transform Fault and its extension to western Lefkada Island (Greece). Tectonophysics 308:223-236

McNeill LC, Collier REL (2004) Uplift and slip rates of the eastern Eliki fault segment, Gulf of Corinth, Greece, inferred from Holocene and Pleistocene terraces. J Geol Soc London 161:81-92 doi:10.1144/0016-764903-029

Melis NS, Burton PW (1988) Seismicity and Crustal Deformation in Regions of Central Greece. Geophysical Journal-Oxford 92:529-529

Nielsen C (2003) Etude des zones de subduction en convergence hyper-oblique: exemples de la ride méditerranéenne et de la marge indo-birmane. Université Paris-Sud

Nishiizumi K, Imamura M, Caffee MW, Southon JR, Finkel RC, McAninch J (2007) Absolute calibration of Be-10 AMS standards. Nucl Instrum Meth B 258:403-413 doi:10.1016/j.nimb.2007.01.297

Papanikolaou D, Alexandri M, Nomikou P (2006) Active faulting in the north Aegean basin. Geol S Am S 409:189-209 doi:10.1130/2006.2409(11)

Papazachos B, Papazachou C (1997) The Earthquakes of Greece P. Ziti and Co, Thessaloniki, Greece

Pearce FD, Rondenay S, Sachpazi M, Charalampakis M, Royden LH (2012) Seismic investigation of the transition from continental to oceanic subduction along the western Hellenic Subduction Zone. J Geophys Res-Sol Ea 117 doi:10.1029/2011JB009023

Perouse E (2013) Cinématique et tectonique active de l'Ouest de la Grèce dans le cadre géodynamique de la Méditerranée Centrale et Orientale. Université Orsay - Paris Sud, Paris XI

Perouse E, Chamot-Rooke N, Rabaute A, Briole P, Jouanne F, Georgiev I, Dimitrov D (2012) Bridging onshore and offshore present-day kinematics of central and eastern Mediterranean: Implications for crustal dynamics and mantle flow. Geochem Geophy Geosy 13 doi:10.1029/2012gc004289

Rohais S, Eschard R, Ford M, Guillocheau F, Moretti I (2007a) Stratigraphic architecture of the Plio-Pleistocene infill of the Corinth Rift: Implications for its structural evolution. Tectonophysics 440:5-28 doi:10.1016/j.tecto.2006.11.006

Rohais S, Joannin S, Colin J-P, Suc J-P, Guillocheau F, Eschard R (2007b) Age and environmental evolution of the syn-rift fill of the southern coast of the Gulf of Corinth (Akrata-Derveni region, Greece). Bulletin de la Société géologique de France 178:231-243

Schimmelpfennig I, Benedetti L, Finkel R, Pik R, Blard PH, Bourles D, Burnard P, Williams A (2009) Sources of in-situ Cl-36 in basaltic rocks. Implications for calibration of production rates. Quat Geochronol 4:441-461 doi:10.1016/j.quageo.2009.06.003 
Schimmelpfennig I, Benedetti L, Garreta V, Pik R, Blard PH, Burnard P, Bourles D, Finkel R, Ammon K, Dunai $\mathrm{T}$ (2011) Calibration of cosmogenic Cl-36 production rates from $\mathrm{Ca}$ and $\mathrm{K}$ spallation in lava flows from Mt. Etna (38 degrees N, Italy) and Payun Matru (36 degrees S, Argentina). Geochim Cosmochim Ac 75:2611-2632 doi:10.1016/j.gca.2011.02.013

Serpetsidaki A, Elias P, Ilieva M, Bernard P, Briole P, Deschamps A, Lambotte S, Lyon-Caen H, Sokos E, Tselentis G-A (2014) New constraints from seismology and geodesy on the $\mathrm{Mw}=6.42008$ Movri (Greece) earthquake: evidence for a growing strike-slip fault system. Geophys J Int 198:1373-1386

Siame L, Bellier O, Braucher R, Sebrier M, Cushing M, Bourles D, Hamelin B, Baroux E, de Voogd B, Raisbeck G, Yiou F (2004) Local erosion rates versus active tectonics: cosmic ray exposure modelling in Provence (south-east France). Earth Planet Sc Lett 220:345-364 doi:10.1016/S0012-821x(04)00061-5

Sorel D (1976) Etude néotectonique dans l'arc Egéen externe occidental : les îles Ioniennes de Céphalonie et Zanthe et de l'Elide occidentale (Grèce). Univeristé de Paris-Sud

Sorel D (1989) L'évolution structurale de la Grèce nord-occidentale depuis le Miocène, dans le cadre géodynamique de l'arc égéen. Université de Paris-Sud

Speranza F, Minelli L, Pignatelli A, Chiappini M (2012) The Ionian Sea: The oldest in situ ocean fragment of the world? J Geophys Res-Sol Ea 117 doi:10.1029/2012jb009475

Stiros S, Moschas F, Feng LJ, Newman A (2013) Long-term versus short-term deformation of the meizoseismal area of the 2008 Achaia-Elia (M-W 6.4) earthquake in NW Peloponnese, Greece: Evidence from historical triangulation and morphotectonic data. Tectonophysics 592:150-158 doi:10.1016/j.tecto.2013.02.016

Stone JO, Allan GL, Fifield LK, Cresswell RG (1996) Cosmogenic chlorine-36 from calcium spallation. Geochim Cosmochim Ac 60:679-692 doi:10.1016/0016-7037(95)00429-7

Underhill JR (1989) Late Cenozoic deformation of the Hellenide foreland, western Greece. Geological Society of America Bulletin 101:613-634

Vassilakis E, Royden L, Papanikolaou D (2006) Extensional neotectonic structures adjacent and sub-parallel to the Hellenic trench. GSA Abstracts with Programs, Vol 38/7, Philadelphia

Vassilakis E, Royden L, Papanikolaou D (2011) Kinematic links between subduction along the Hellenic trench and extension in the Gulf of Corinth, Greece: A multidisciplinary analysis. Earth Planet Sc Lett 303:108-120 doi:10.1016/j.eps1.2010.12.054

Vermeesch P (2007) CosmoCalc: An Excel add-in for cosmogenic nuclide calculations. Geochem Geophy Geosy 8 doi:10.1029/2006gc001530

Wallace RE (1978) Geometry and rates of change of fault-generated range fronts, northcentral Nevada. Journal of Research of the US Geological Survey 6:637-649

Zerathe S, Braucher R, Lebourg T, Bourles D, Manetti M, Leanni L (2013) Dating chert (diagenetic silica) using in-situ produced Be-10: Possible complications revealed through a comparison with Cl-36 applied to coexisting limestone. Quat Geochronol 17:81-93 doi:10.1016/j.quageo.2013.01.003 


\section{Tables}

Table 1: Measured cosmogenic ${ }^{36} \mathrm{Cl}$ and natural ${ }^{35} \mathrm{Cl}$ concentrations of samples collected along the depth profile at the sampling site (Figs. 13, 14).

\begin{tabular}{|c|c|c|c|c|c|}
\hline Sample & $\begin{array}{c}\text { Depth } \\
\text { (cm) }\end{array}$ & $\underset{\text { (at/gr.) }}{\text { Measured }}$ & $\begin{array}{c}\text { Error } \\
\text { measured }{ }^{36} \mathrm{Cl}( \pm \\
\text { at/gr.) }\end{array}$ & $\begin{array}{l}\text { Natural 35Cl } \\
\quad(\mathbf{p p m})\end{array}$ & Geologic material \\
\hline $\mathrm{Cl} 01$ & 20 & 114310 & 4290 & 25.55 & \multirow{3}{*}{ Historic colluviums } \\
\hline $\mathrm{Cl} 03$ & 60 & 109270 & 3614 & 15.93 & \\
\hline $\mathrm{Cl} 06$ & 120 & 147333 & 4754 & 29.10 & \\
\hline $\mathrm{Cl} 07$ & 140 & 249731 & 5883 & 6.89 & \multirow{9}{*}{ Alluvial fan } \\
\hline $\mathrm{Cl} 08$ & 160 & 171920 & 4357 & 4.06 & \\
\hline $\mathrm{Cl} 09$ & 180 & 131278 & 4247 & 11.12 & \\
\hline $\mathrm{Cl} 10$ & 200 & 95645 & 3297 & 11.01 & \\
\hline $\mathrm{Cl} 12$ & 240 & 181391 & 4702 & 12.83 & \\
\hline $\mathrm{Cl} 14$ & 275 & 75182 & 2964 & 1.23 & \\
\hline $\mathrm{Cl} 16$ & 330 & 101152 & 3130 & 15.82 & \\
\hline $\mathrm{Cl} 18$ & 400 & 144827 & 4134 & 6.04 & \\
\hline $\mathrm{Cl} 21$ & 530 & 152744 & 5144 & 8.77 & \\
\hline
\end{tabular}


Table 2: Measured ${ }^{36} \mathrm{Cl}$ concentrations and results of depth profile rejuvenation (Fig. 15b). ${ }^{36} \mathrm{Cl}$ half-life is $301 \mathrm{ka}$ (Gosse and Phillips 2001). Scaling factor for surface nucleonic and muonic production as a function of latitude and altitude are respectively 1.01 and 0.97 (Stone et al. 1996) and have been calculated using CosmoCalc (Vermeesch 2007). We input a bulk rock density of 1.8 . Production ${ }^{36} \mathrm{Cl}$ rates and modeling results have been obtained using Excel spreadsheet of (Schimmelpfennig et al. 2009). Spallation production rate from Ca is $\sim 42$ atoms ${ }^{36} \mathrm{Cl}$. g. $\mathrm{Ca}^{-1}$ (Braucher et al. 2011; Schimmelpfennig et al. 2011). We considered no denudation.

\begin{tabular}{|c|c|c|c|c|c|c|}
\hline Sample & $\begin{array}{c}\text { Depth } \\
\text { (cm) }\end{array}$ & $\begin{array}{l}\text { Nmeas: } \\
\text { Measured } \\
{ }^{36} \mathrm{Cl} \\
\text { (at/gr.) }\end{array}$ & $\begin{array}{c}\text { Error } \\
\text { Nmeas } \\
( \pm \text { at/gr.) }\end{array}$ & $\begin{array}{c}\text { Nth: } \\
\text { Theoretical }{ }^{36} \mathrm{Cl} \\
\text { for modeled age } \\
\text { of } 10.158 \mathrm{ka} \\
\text { (at/gr.) }\end{array}$ & $\begin{array}{c}\text { Error } \\
\text { Nth } \\
\text { (at/gr.) }\end{array}$ & $\begin{array}{c}\text { Excess } \\
\text { concentration } \\
(=\text { Nmeas - Nth }) \\
(\text { at/gr. })\end{array}$ \\
\hline $\mathrm{Cl} 07$ & 20 & 249731 & 5883 & 164721 & 47657 & 85009 \\
\hline $\mathrm{Cl} 08$ & 40 & 171920 & 4357 & 137440 & 38296 & 34480 \\
\hline $\mathrm{Cl} 09$ & 60 & 131278 & 4247 & 114464 & 30875 & 16814 \\
\hline $\mathrm{Cl} 10$ & 80 & 95645 & 3297 & 95645 & 25004 & 0 \\
\hline $\mathrm{Cl} 12$ & 120 & 181391 & 4702 & 68085 & 16749 & 113306 \\
\hline Cl 14 & 155 & 75182 & 2964 & 51971 & 12240 & 23211 \\
\hline $\mathrm{Cl} 16$ & 210 & 101152 & 3130 & 36091 & 8319 & 65061 \\
\hline $\mathrm{Cl} 18$ & 280 & 144827 & 4134 & 25281 & 6239 & 119545 \\
\hline $\mathrm{Cl} 21$ & 410 & 152744 & 5144 & 16810 & 4922 & 135934 \\
\hline
\end{tabular}

Table 3: Maximum modeled ages obtained by depth profile rejuvenation considering different denudation rate values $(\varepsilon)$.

\begin{tabular}{cc}
\hline $\begin{array}{c}\text { Denudation rate } \boldsymbol{\varepsilon} \\
(\mathbf{m} / \mathbf{M a})\end{array}$ & $\begin{array}{c}\text { Maximum modeled } \\
\text { age }(\mathbf{y r} .)\end{array}$ \\
\hline 0 & 10157.9 \\
5 & 10387.2 \\
20 & 11155.4 \\
30 & 11746.3 \\
\hline
\end{tabular}




\section{Figure Captions}

Fig. 1 Geodynamic setting of Western Greece. Tectonic structures and crust nature are from Chamot-Rooke et al. (2005) and Papanikolaou et al. (2006). Velocity vectors, relative to fixed Eurasia, are from the regional interpolated velocity field (Perouse et al. 2012). AP: Apulian Platform; CR: Corinth Rift; CSZ: Calabrian Subduction Zone; KF: Kefalonia Fault; NAF: North Anatolian Fault; Pel: Peloponnesus. Black structures are active, grey ones are inactive (cf. Perouse et al. 2012). The blue star is the rotation pole of the Apulian-Ionian microplate relative to Nubian plate, shown with its 95\% confidence ellipse (Perouse et al. 2012).

Fig. 2 Instrumental seismicity in the Western Greece region. Focal mechanisms of superficial events $(<30 \mathrm{~km})$ from the Harvard CMT catalog (1976 to 2007) and the Regional CMT catalog (1995 to 2007) have been relocalized according to the Engdahl catalog (Engdahl et al. 1998). Compressional quadrants of focal mechanisms: blue, red and green indicate reverse, strike slip and normal faulting, respectively. Seismicity distribution of superficial events $(<30$ $\mathrm{km}$ ), with magnitude $\mathrm{Ml}>3.7$, is plotted in yellow (from NOA catalog, 1970 to 2008).

Fig. 3 Tectonic map of Western Greece showing active (red) and inactive (black) faults. Lou: Loutraki fault; Tri: Trichonis Lake. Fault traces from the present study: Loutraki and KSF. Fault traces from other studies: onshore Ionian islands (Cushing 1985; Nielsen 2003); offshore Amvrakikos (Anastasakis et al. 2007); Trichonis graben (Perouse 2013); Patras Gulf (Ferentinos et al. 1985); Corinth Rift (Jolivet et al. 2010); Apulian collision front, Hellenic backstop, Calabrian prism (Chamot-Rooke et al. 2005); Achaia-Elia fault (e.g., Stiros et al. 2013), N-striking Akarnania thrusts (Clews 1989, see Fig. 4 for details). Hellenides units: yellow, Pre-Apulian zone (PA zone), purple, Ionian zone, brown, Gavrovo-Tripolitza (Gvo- 
Tz) and green, Pindos unit (Aubouin 1959; British Petroleum Co Ltd 1971; Karakitsios and Rigakis 2007). Neogene and Quaternary deposits in white. Inset: regions names. Aka: Akarnania; Aito: Aitolia; Pelop: Peloponnesus.

Fig. 4 Map of the KSF system. Active (red) and inactive (black) fault traces. Lou: Loutraki Fault; Kat: Katouna Fault; Sta: Stamna Fault; Amph: Amphilochia valley; Amv: Amvrakia Lake; Oz: Ozeros Lake. The Neogene Hellenides Akarnania thrusts are shown as Pal: Paleros thrust; Myt: Mytikas thrust; Ast: Astakos thrust. (a) Topography background, SRTM (3seconds resolution); (b) Simplified geological map based on our reappraisal and geological maps (British Petroleum Co Ltd 1971; Institute of Geology and Mineral Exploration, IGME, 1987). Sealed thrusts are shown with dashed lines.

Fig. 5 (a) Morphological map of Loutraki and Katouna Faults. Topography background with height contours, SRTM (3 seconds resolution). Main drainage network is in blue. Solid roundish-shaped black lines: wine glass valleys; dashed black line: benches on Loutraki fault escarpment. (b) Simplified geological background (same captions as Fig. 4b). The FP yellow point is a normal fault plan $\mathrm{N} 120^{\circ} 55^{\circ} \mathrm{N} 85^{\circ} \mathrm{E}$, between Mesozoic limestones and old alluvial fan deposits $\left(38.864572^{\circ} \mathrm{N}, 21.070004^{\circ} \mathrm{E}\right)$.

Fig. 6 Topographic profiles across the Loutraki and Katouna Faults, with vertical exaggeration $(\times 3)$. Profile lines are plotted in Fig. 5. H: escarpment height; EFT: Escarpment Flat Top; blue arrows: benches. Red arrows: active faults. 
Fig. 7 Geological cross section through the Katouna and Amphilochia valley, based on the 1:50,000 Amphilochia geological map (Institute of Geology and Mineral Exploration, IGME, 1987), and interpretative Katouna fault geometry. Section line is plotted in Figs. 4, 5.

Fig. 8 Offset streams along the southern Katouna fault. Sites locations are plotted on Fig. 5. Site (a) displays three stream offsets. The field photograph and the enlarged inset show a close-up of two small stream offsets of 5-7m and $\sim 12 \mathrm{~m}$, respectively. Site (b) displays a $\sim 40$ $\mathrm{m}$ offset stream. Site (c) is an offset stream with a $54 \pm 4 \mathrm{~m}$ offset. Satellite images from Google Earth.

Fig. 9 (a) SRTM (3 seconds resolution) of Stamna area and (b) interpreted Stamna active fault segment.

Fig. 10 Drainage network along the Stamna Fault (satellite image from Google Earth, see Fig. 9 for location). FP: Fault Plane shown in Fig. 11, close to the freeway bridge.

Fig. 11 Fault plane measured within Plio-Pleistocene alluvial deposits (location on Fig. 10). Fault plane is $\mathrm{N} 162^{\circ} 65^{\circ} \mathrm{W}$, with a $13^{\circ} \mathrm{S}$ dipping slickenside (underline by red line), indicating a nearly pure left-lateral slip.

Fig. 12 Field photographs of the N-striking Neogene thrusts in central Akarnania. Location of thrusts on Fig. 4a. (a) View of the Astakos thrust sealed by strong calcite-cemented breccias ( $\mathrm{SBr}$ ). SBr consists of cryoclastic angular elements of Ionian Mesozoic limestone with no clay matrix attributed to the Middle Pleistocene (Sorel 1976); (b) Landslide head scar along the Astakos thrust. White arrows indicate this head scar. The destroyed house on the left attests 
for a recent landslide movement. Inset shows the scar of the last movement. PBr: poorly consolidated slope breccias. They may correlate with either Holocene or the last climatic crisis coeval with LGM (i.e., MIS 2); (c) W-facing discontinuous cliff made of Ionian Mesozoic limestone covered by strongly cemented slope breccias ( $\mathrm{SBr}$ ) seen along the Paleros thrust. This cliff height displays an along-strike variation (red arrows) resulting from gully differential erosion between the limestone material and the Miocene molasses.

Fig. 13 Conceptual 3D block diagram summarizing tectonic and geomorphologic field observations seen on the N-striking Akarnania thrusts (Fig. 12) and interpretations.

Fig. 14 Selected left-lateral offset stream to perform CRE dating and location of the sampling site. (a) Local geological map (close-up of Fig. 5) showing the catchment area of the selected offset stream. (b) Satellite image of the offset stream as on Fig. 8c. Measured offset stream is $54 \pm 4 \mathrm{~m}$ (50m minimum considering near-field piercing points, see Suppl. Material Fig. S2). P: sampling site location of depth profiles for CRE dating (Fig. 15). (c) Field photograph (looking SW) of the analyzed offset stream. The green almond shaped patch facing the upstream gorge corresponds to a shutter ridge. Purple wooded area in the background corresponds to the Triassic breccias bedrock of the KSF escarpment; in the foreground, green color corresponds to alluvial fan material and slope screes aggraded on the hangingwall block.

Fig. 15 Sampling site of depth profiles used for CRE dating (located as P on Fig. 14b). Geographic coordinates: $38.79077^{\circ} \mathrm{N}, 21.13115^{\circ} \mathrm{E}$. Profile altitude: $95 \mathrm{~m}$. No significant shielding affects the fan surface (maximal values $~ 10 \%$ ). (1) Historic colluviums with heterometric clasts and anthropic elements (tiles, bricks, pottery sherds); (2) Alluvial fan material with heterometric carbonates and cherts clasts within a sandy matrix; PS: pebbly 
layer; MS: muddy layer with sparse and small angular clasts within a silty-clayed matrix; (3) Alluvial fan material with fairly homometric carbonates and cherts clasts within a sandy matrix.

Fig. 16 Measured ${ }^{36} \mathrm{Cl}$ and ${ }^{10} \mathrm{Be}$ concentrations as a function of depth (values in Table 1 and Suppl. Material, Table S1). ${ }^{36} \mathrm{Cl}$ and ${ }^{10} \mathrm{Be}$ have been measured in carbonates and cherts, respectively. This plot emphasizes two distinct origins and pre-exposure histories for carbonates and cherts.

Fig. 17 (a) Measured ${ }^{36} \mathrm{Cl}$ concentrations in carbonate clasts as a function of depth; (b) Rejuvenation depth profile procedure model of ${ }^{36} \mathrm{Cl}$ concentrations (See text for more details). We only consider samples from the alluvial fan material (historic colluviums are not considered, so that the $1.20 \mathrm{~m}$ depth corresponds to the initial fan surface). $\mathrm{t}$, maximum in-situ exposure duration; $\varepsilon$, denudation rate. The best fit is obtained for zero denudation and $\mathrm{Cl} 10$ sample with a measured ${ }^{36} \mathrm{Cl}$ concentration carrying zero inheritance (Table 2). For all the other samples, the differences between the measured and the modeled concentrations result from pre-exposure processes.

Fig. 18 GPS velocity field relative to fixed Akarnania. GPS sites minimized to define this reference frame are shown with green squares. Green diamond site, not used to define the reference frame, shows nonetheless a residual close to zero (See text for discussion). GPS vectors are shown with their $95 \%$ confidence ellipses. Velocity vectors are taken from Hollenstein et al. (2008), Floyd et al. (2010), Briole (2013) and GPSscope data, available at http://crlab.eu 
Fig. 19 Simplified tectonic map of Western Greece. IAB: Ionian Islands-Akarnania Block. Arrows and numbers show relative motions and fault slip-rate values in $\mathrm{mm} / \mathrm{yr}$. Italic numbers refer to GPS slip-rate determined in previous studies (Briole et al. 2000; Perouse et al. 2012). Regular numbers indicate GPS slip-rate assessed in this study. The minimum geological sliprate determined from CRE dating for the Katouna fault is reported as (geol). Dotted areas are diffused deformation zones. Green asterisk and dashed line point to possible incipient fault (See Discussion for details). 
$20^{\circ} \mathrm{E}$

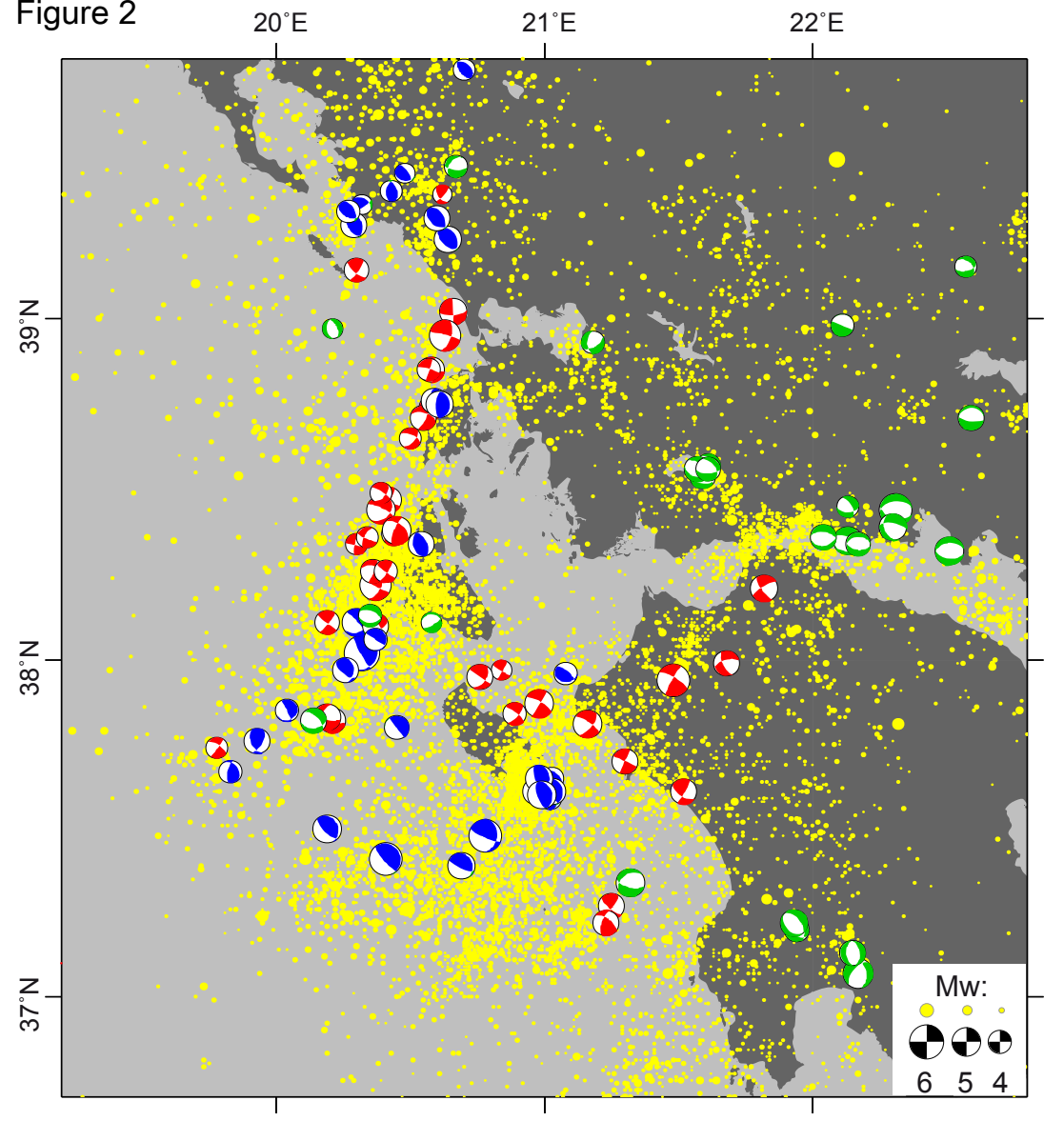




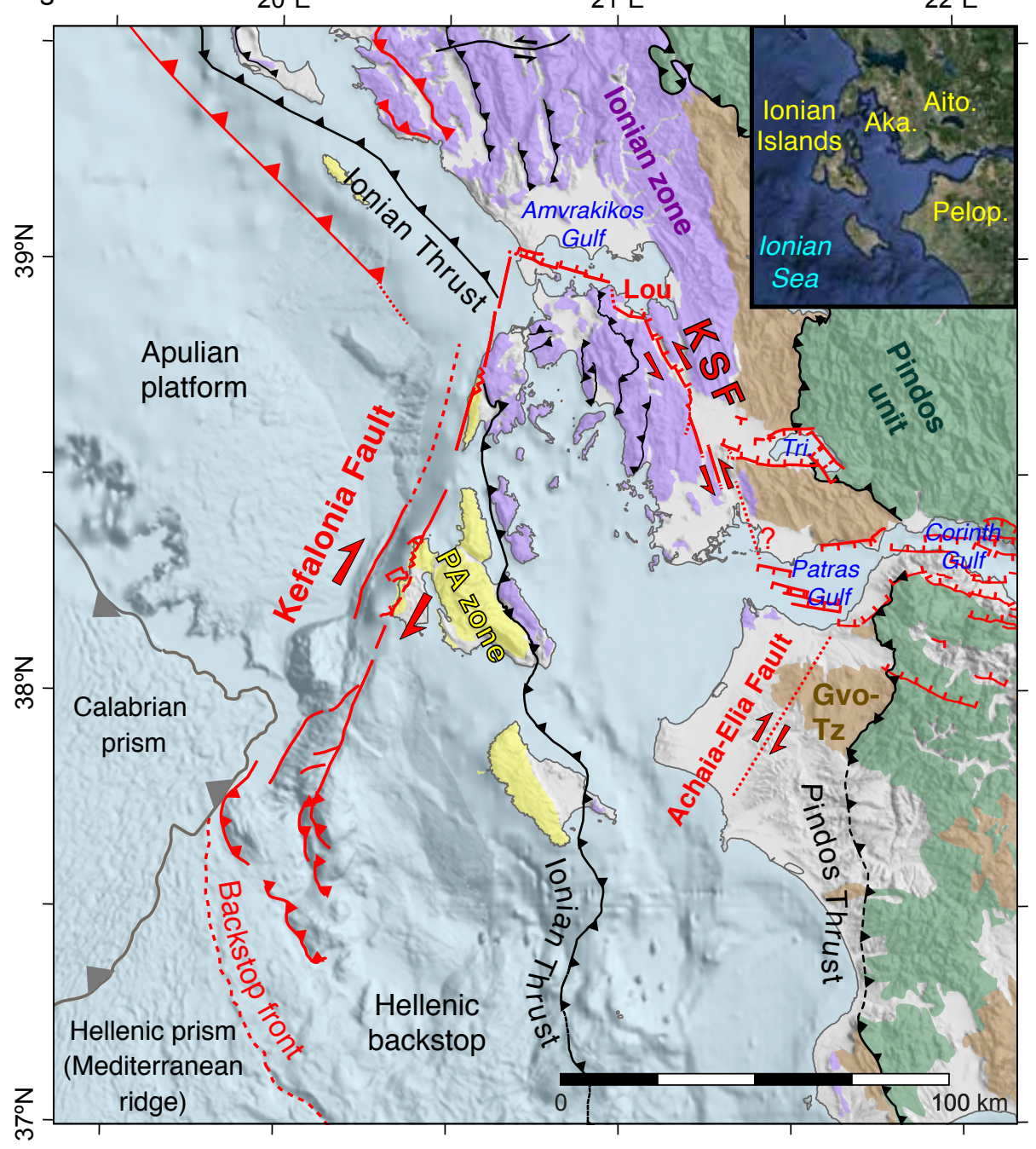


Click herę1.t.2010wnload Figure Fig.4_revised4.pdf $\underline{\underline{E}}$

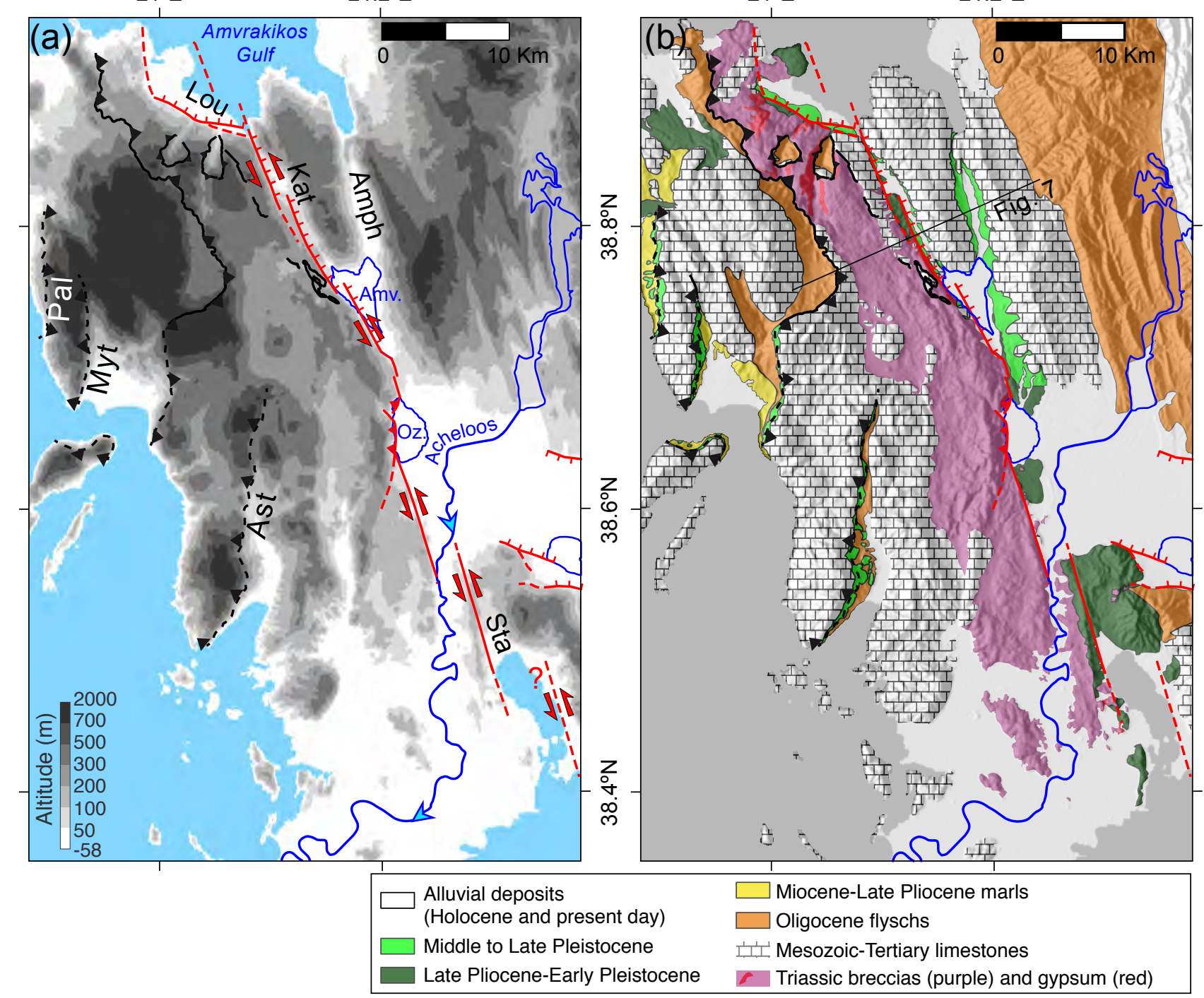



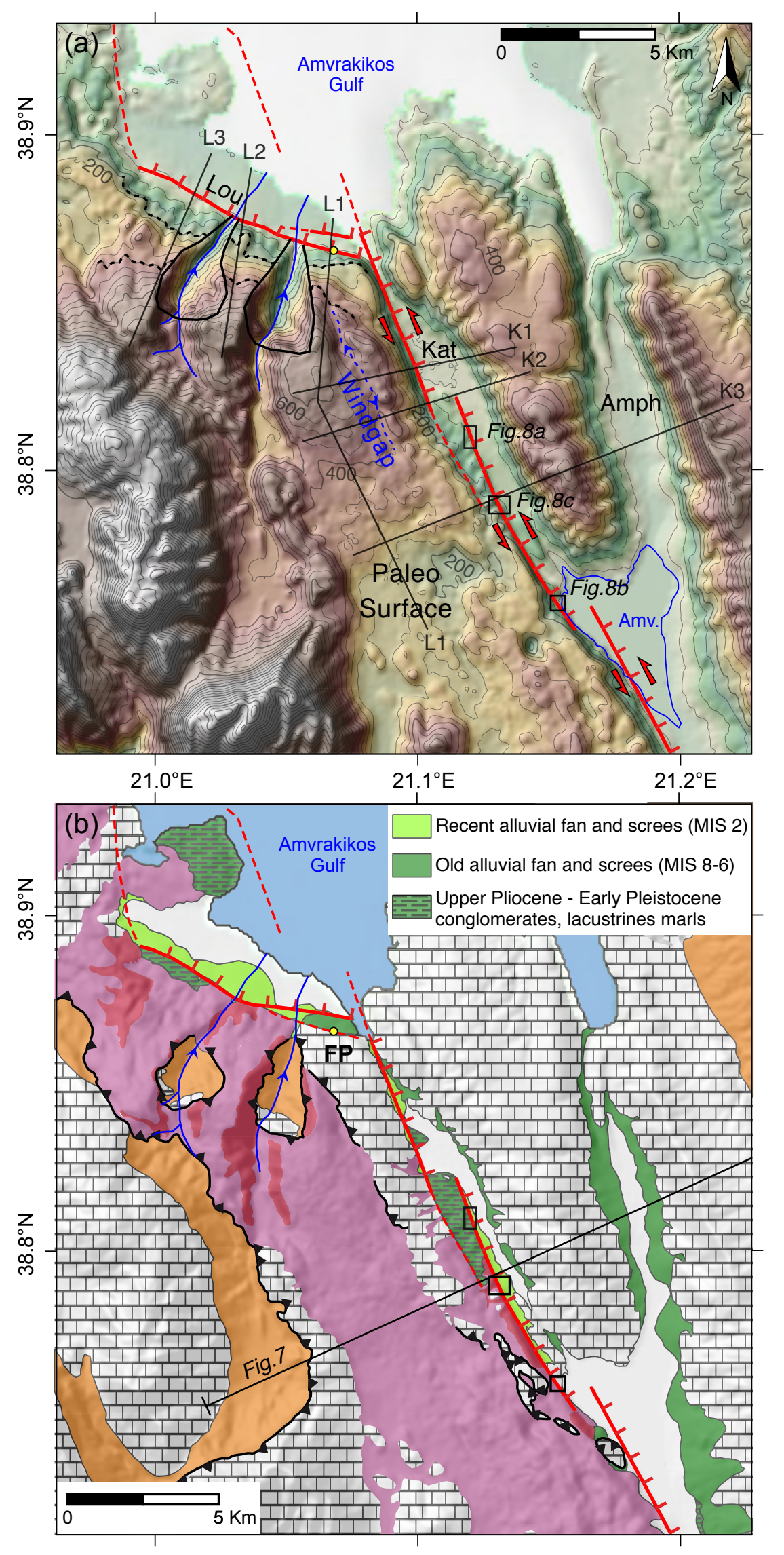

\section{5}

Click here to download Figure Fig.5_revised3.pdf $\underline{\underline{\underline{ }}}$

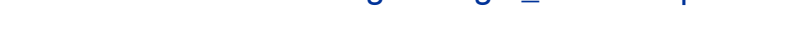

\section{.

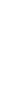

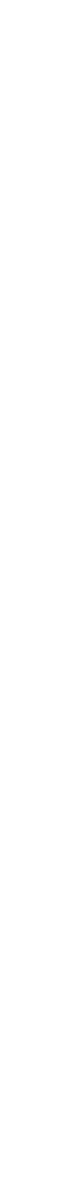
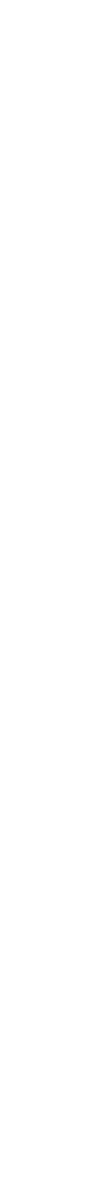

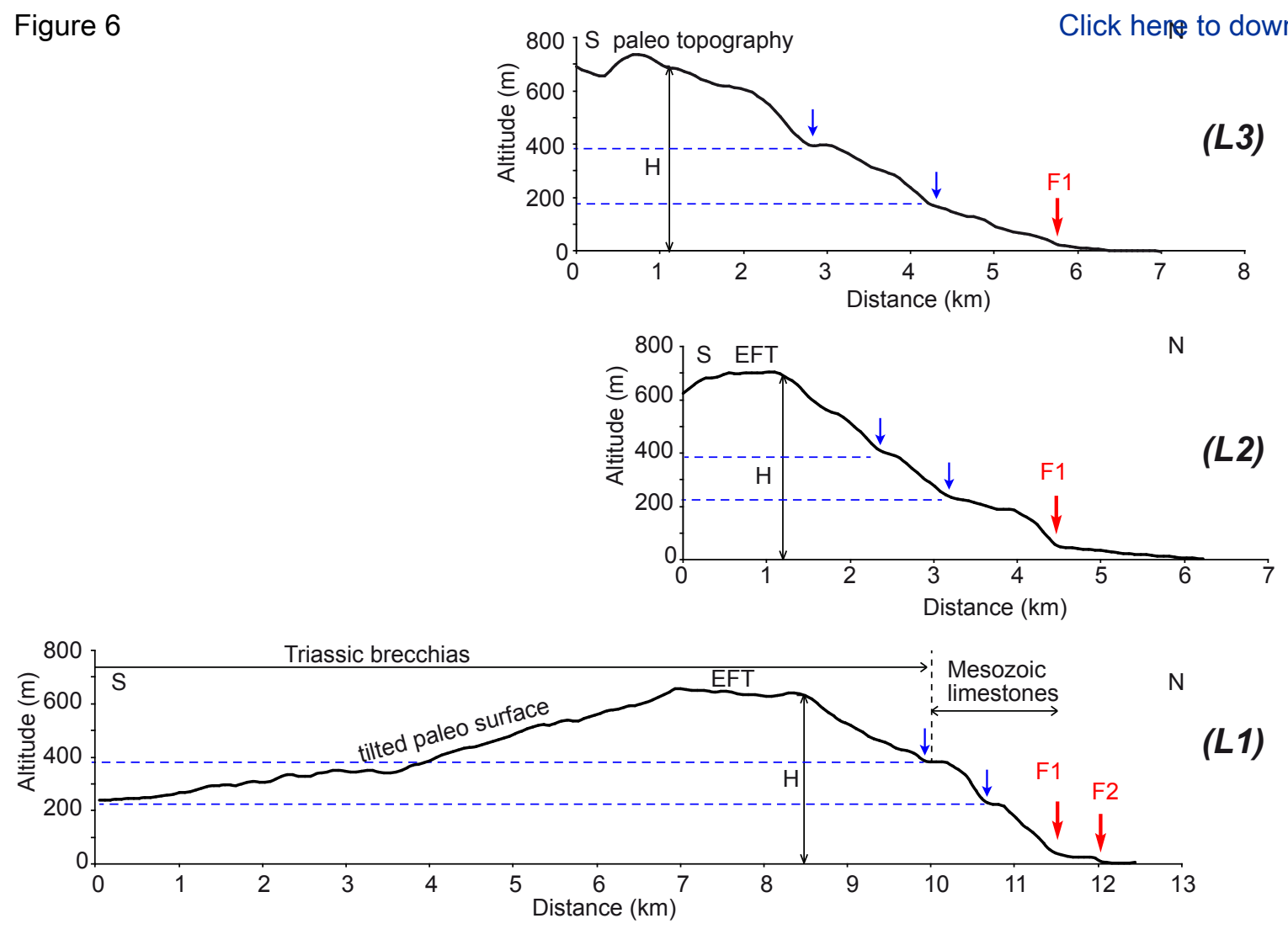

(L1)

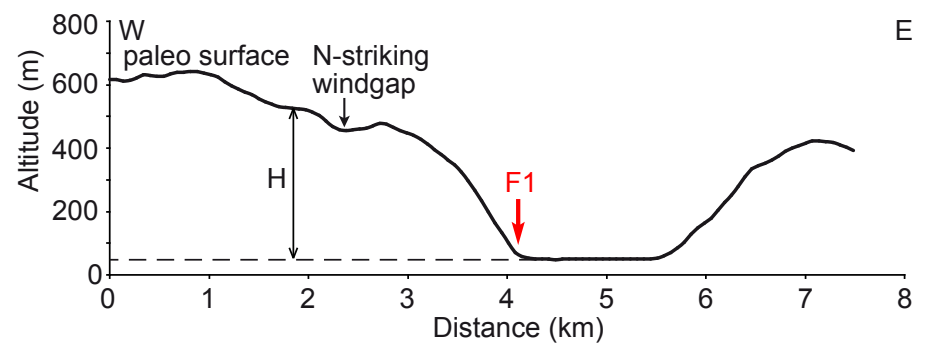

(K1)

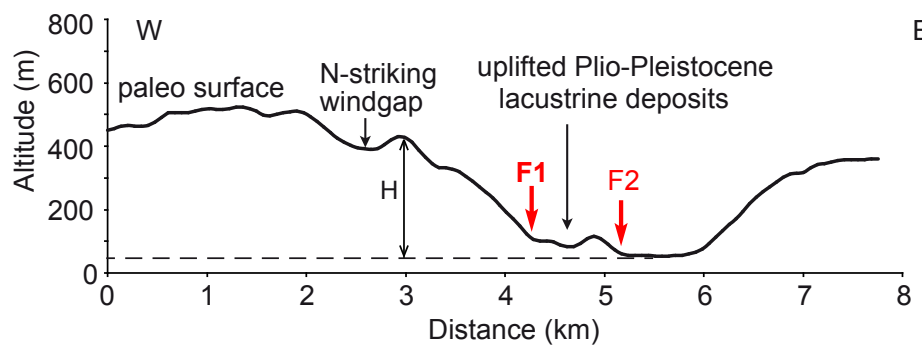

(K2)

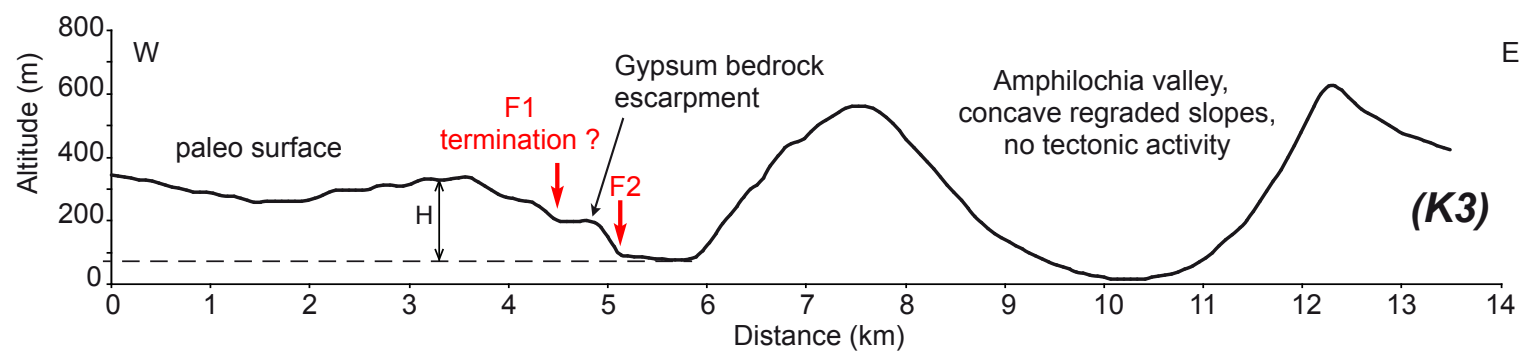


Altitude $(\mathrm{km})$

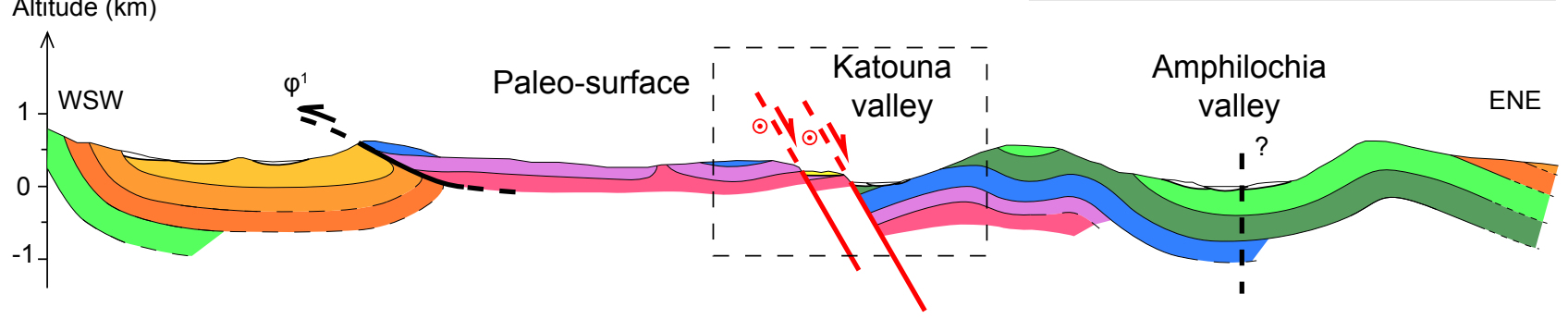

Quaternary

Recent screes, alluvial fan or deposits (Middle Pleistocene to Holocene)

$\begin{array}{ll}\square \text { Oligocene flyschs } & \square \text { Early Creteacous limestones } \\ \square \text { Eocene limestones } & \square \text { Early to Middle Jurassic limestones } \\ \square \text { Paleocene limestones } & \square \text { Triassic carbonate breccias } \\ \square \text { Late Creteacous limestones } & \square \text { Triassic evaporites and gypsum }\end{array}$

lacustrine marls and clays

$0 \mathrm{~m}$

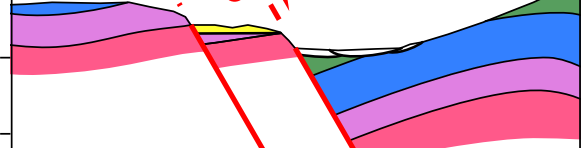

$-500 \mathrm{~m}$

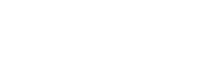



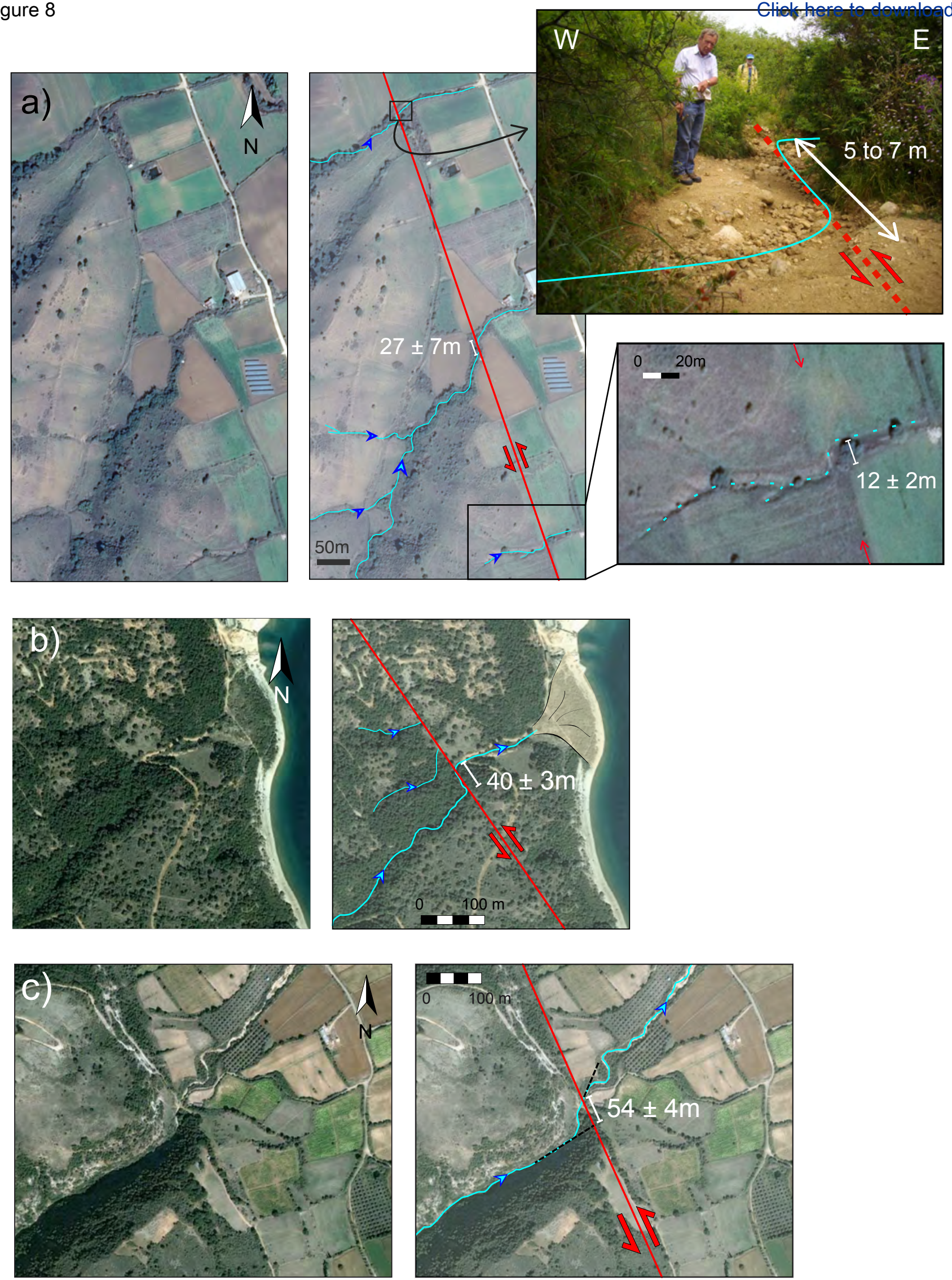


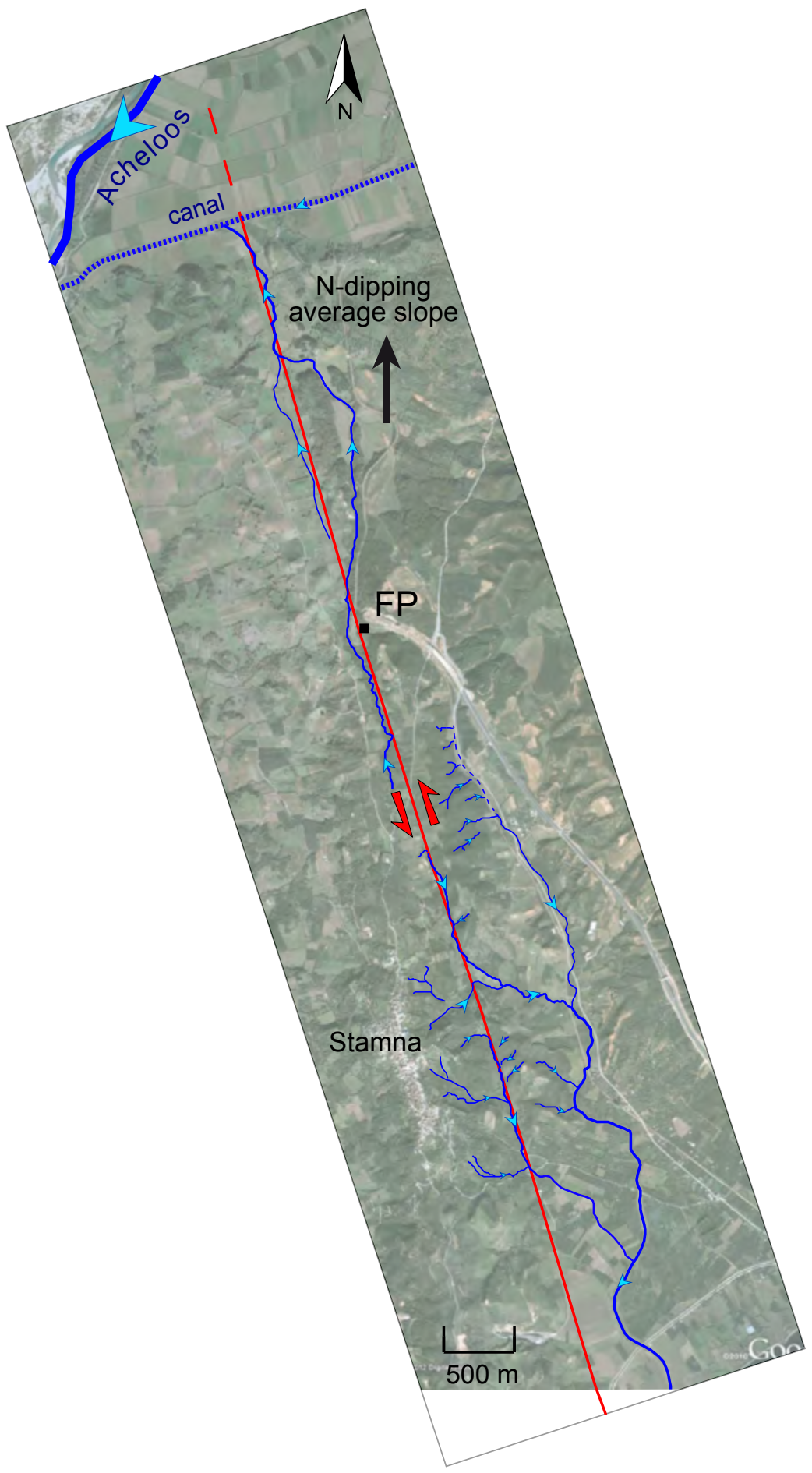




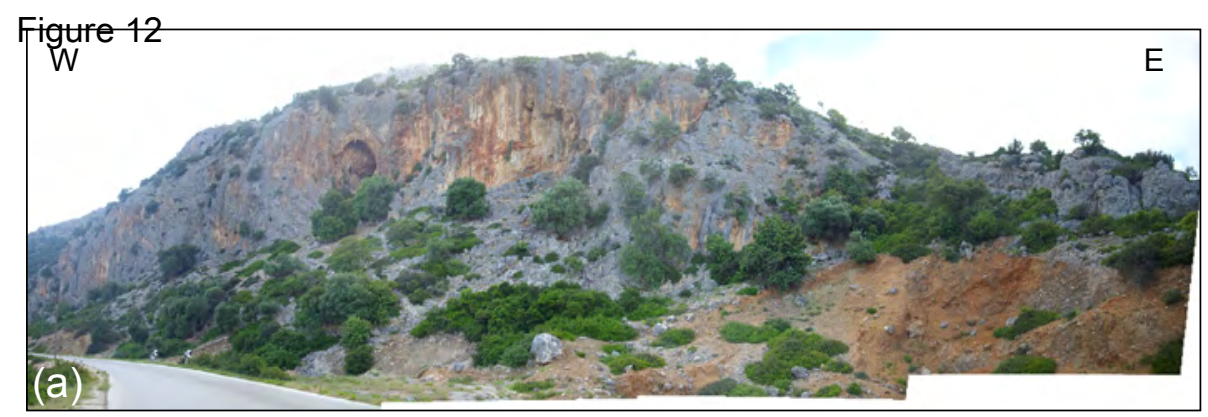

Click here to download Figure Fig.12.pdf $\underline{\underline{\underline{*}}}$
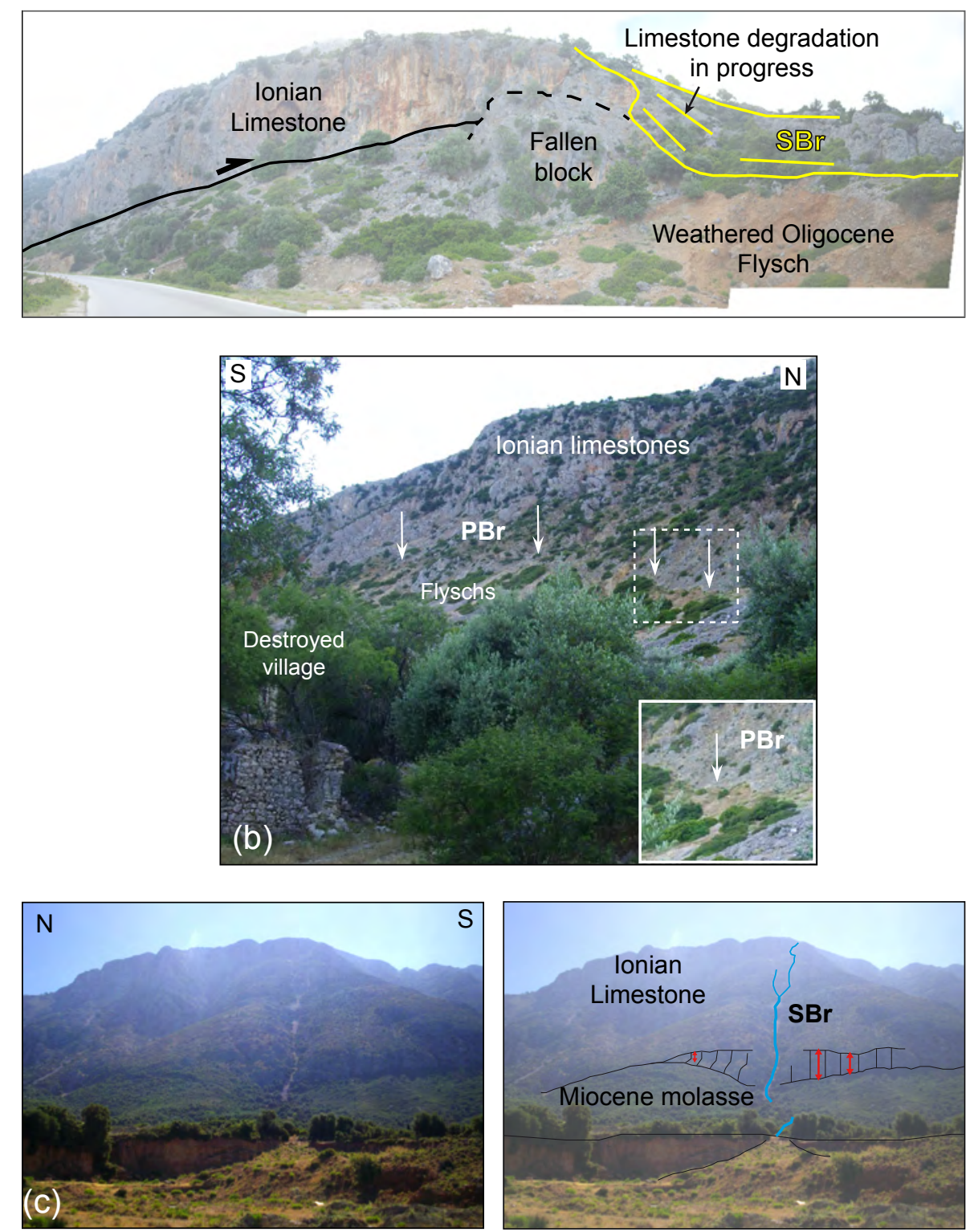


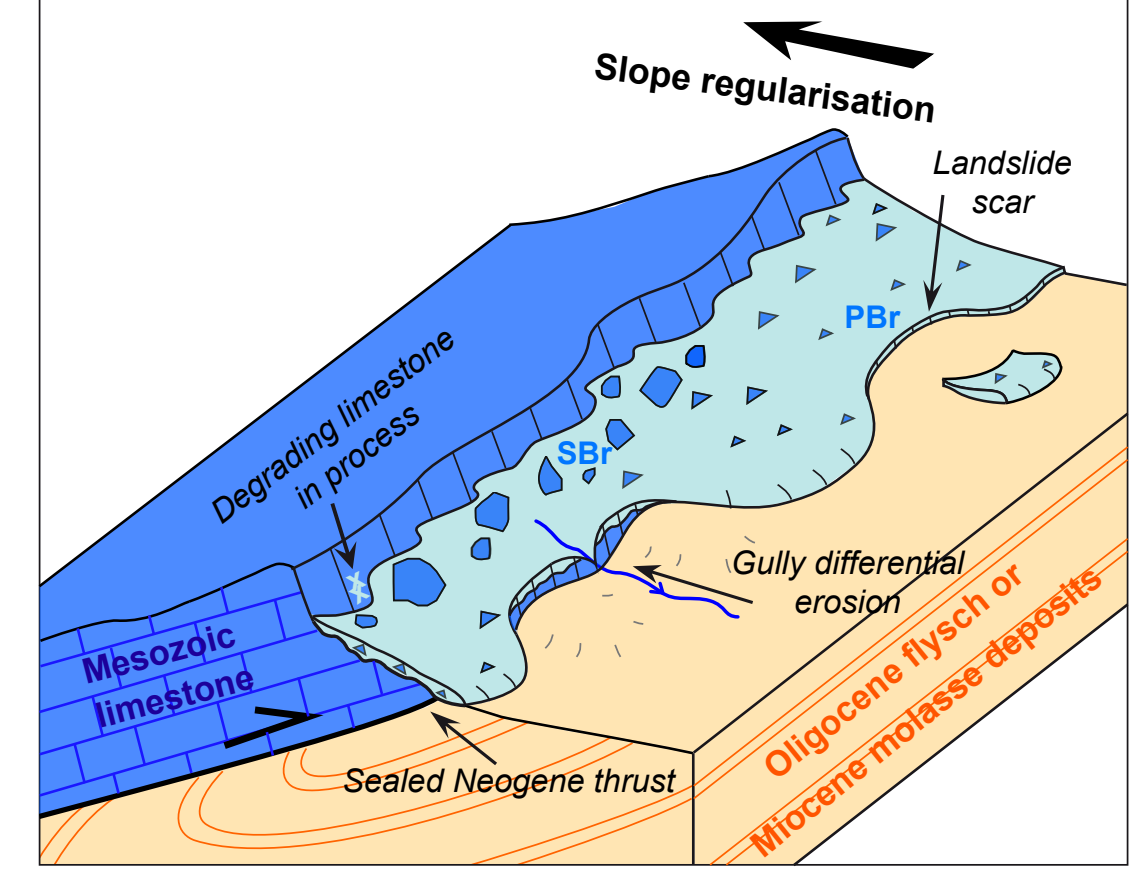



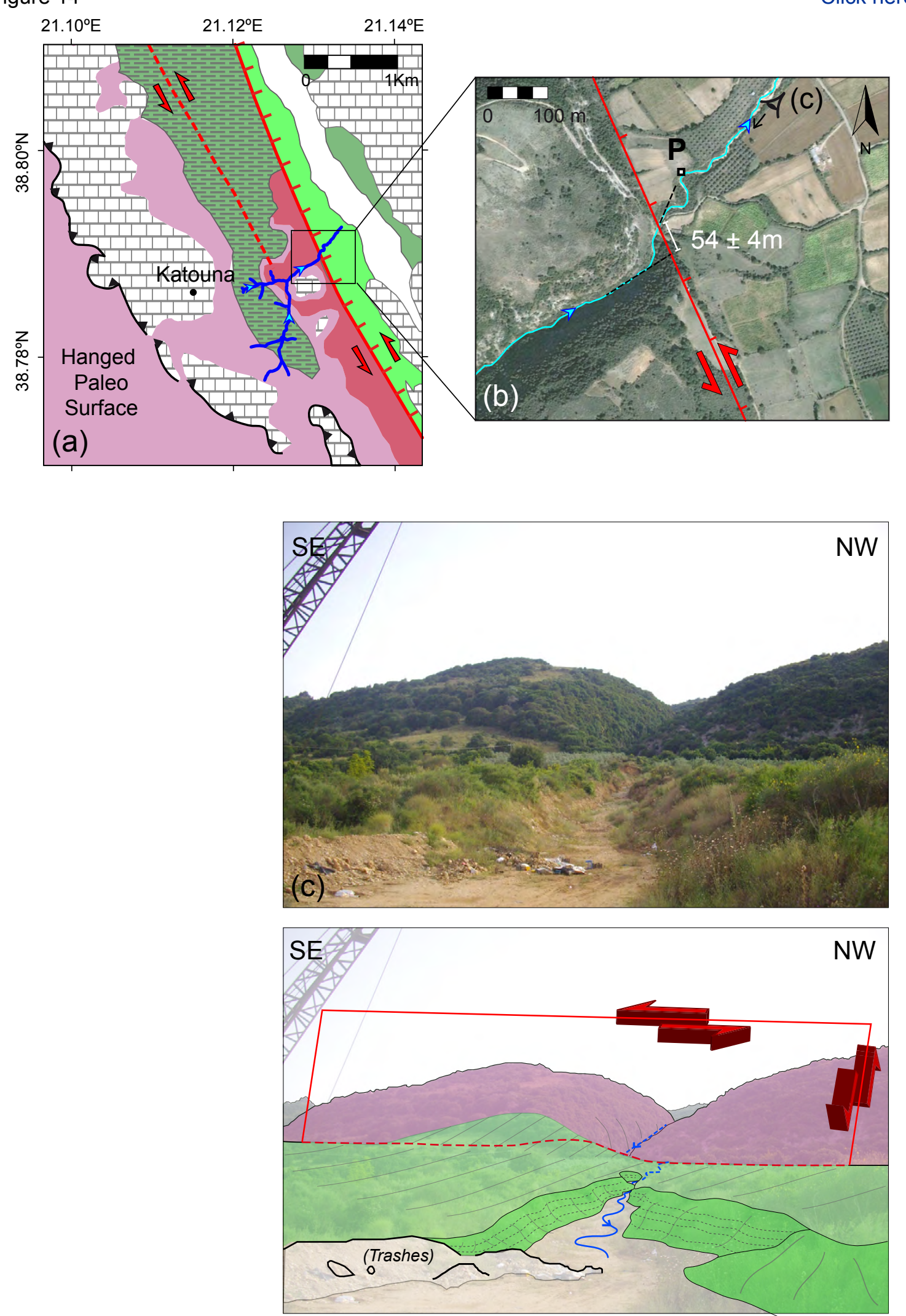

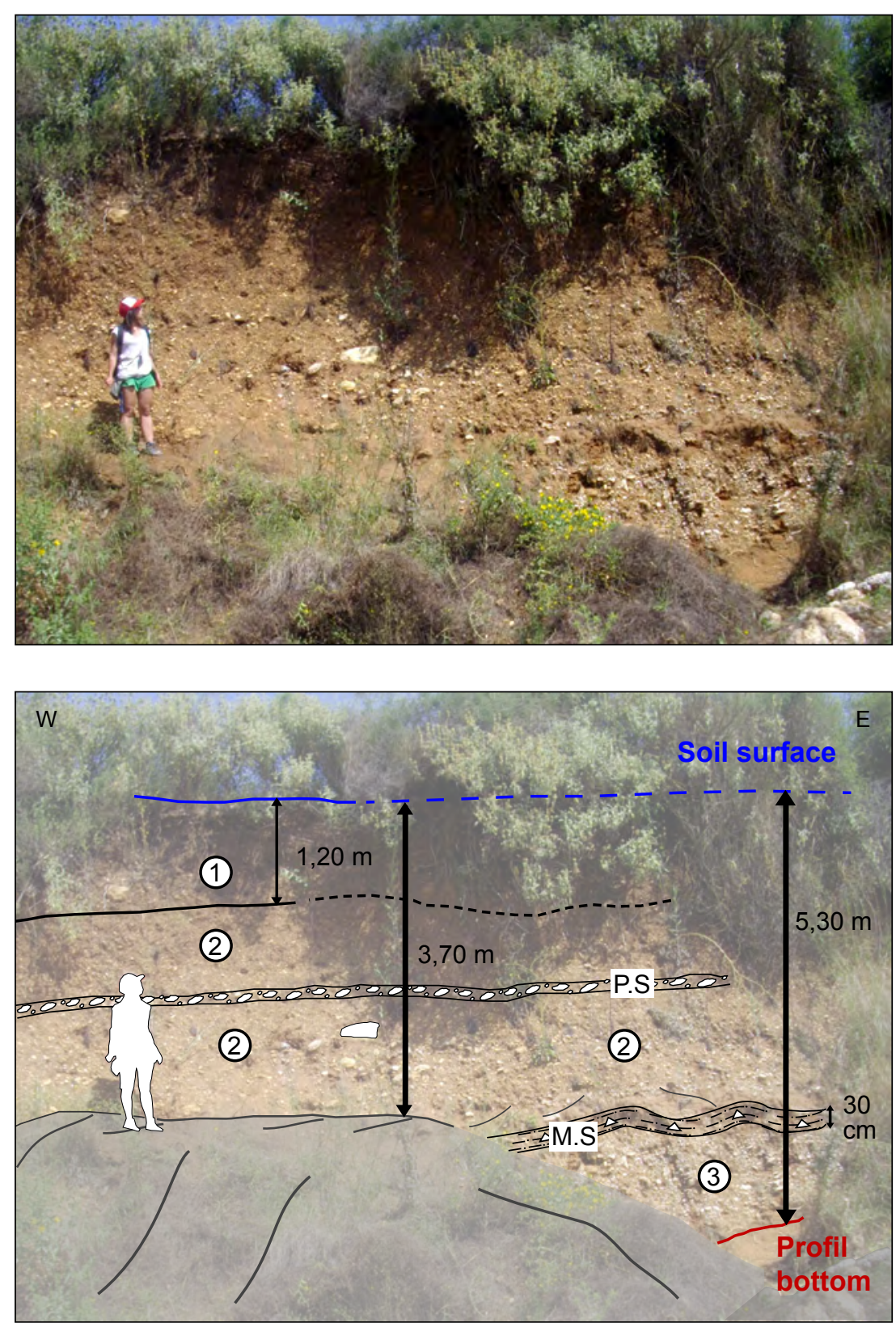
(a) Cosmogenic ${ }^{36} \mathrm{Cl}$ concentration $\left(.10^{3} \mathrm{at} / \mathrm{gr}\right.$.)

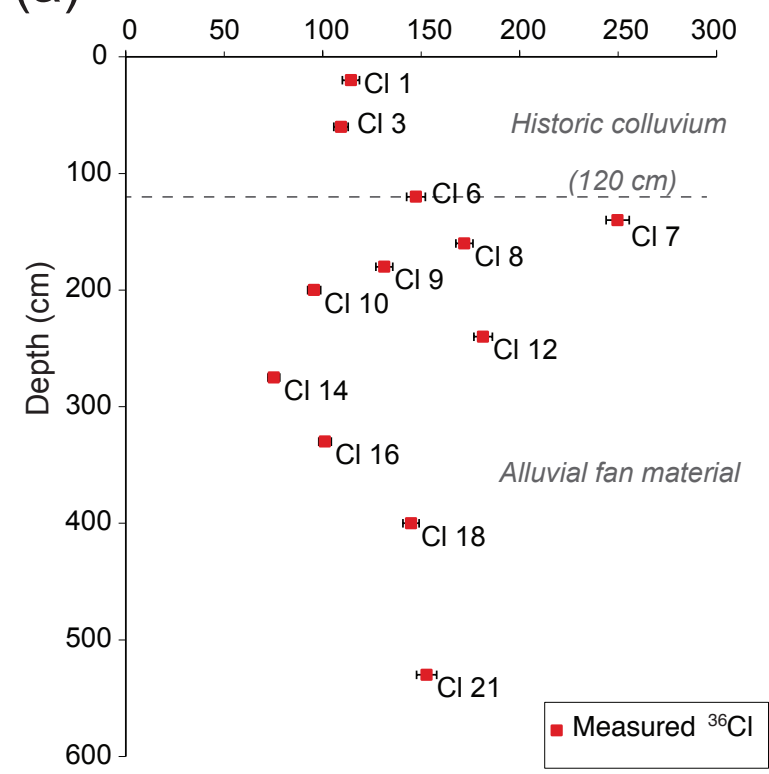

(b)

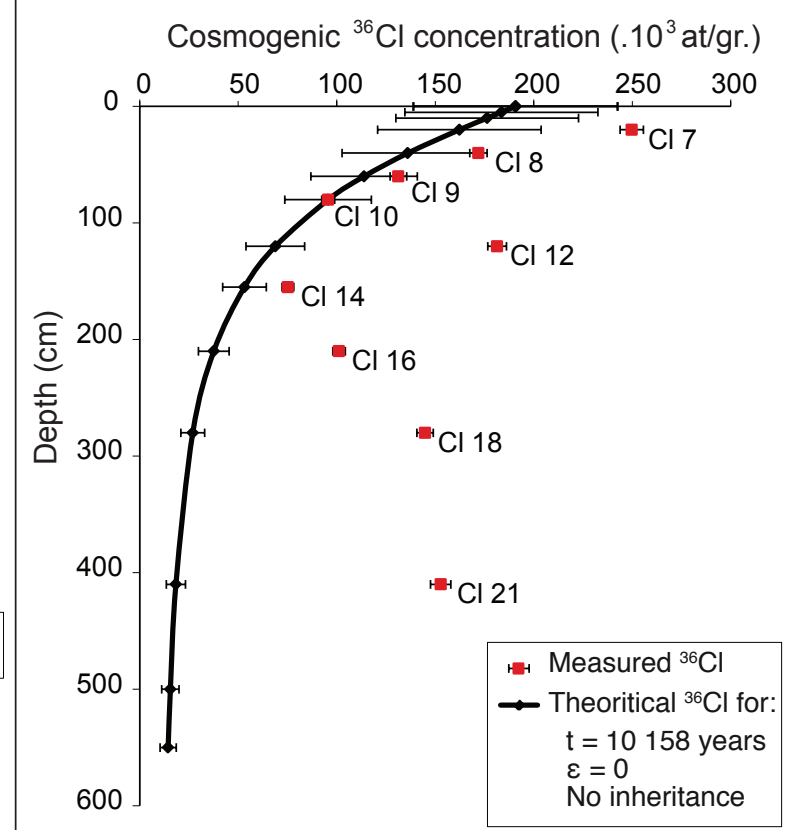


